\title{
Lin28B and Let-7 in the Control of Sympathetic Neurogenesis and Neuroblastoma Development
}

\author{
Melanie Hennchen, ${ }^{1}$ Jutta Stubbusch, ${ }^{1,2,3}$ Ikram Abarchan-El Makhfi, ${ }^{1}$ Marco Kramer,,${ }^{1,2,3}$ Thomas Deller, ${ }^{2}$ \\ Cécile Pierre-Eugene, ${ }^{5}$ Isabelle Janoueix-Lerosey, ${ }^{5}$ Olivier Delattre, ${ }^{5}$ Uwe Ernsberger, ${ }^{1,2,3}$ Johannes B. Schulte, ${ }^{4}$ \\ and Hermann Rohrer ${ }^{1,2,3}$ \\ ${ }^{1}$ Developmental Neurobiology, Max Planck Institute for Brain Research, 60438 Frankfurt am Main, Germany, ${ }^{2}$ Institute of Clinical Neuroanatomy, Goethe \\ University of Frankfurt, 60590 Frankfurt am Main, Germany, ${ }^{3}$ Ernst Strüngmann Institute, 60528 Frankfurt am Main, Germany, ${ }^{4}$ Department of Pediatric \\ Oncology and Haematology, Children's Hospital Essen, 45122 Essen, Germany, and 5Unité Institut National de la Santé et de la Recherche Médicale, U830, \\ Centre de Recherche Institut Curie, 75248 Paris Cedex 05, France
}

The RNA binding protein Lin28B is expressed in developing tissues and sustains stem and progenitor cell identity as a negative regulator of the Let-7 family of microRNAs, which induces differentiation. Lin28B is activated in neuroblastoma (NB), a childhood tumor in sympathetic ganglia and adrenal medulla. Forced expression of Lin28B in embryonic mouse sympathoadrenal neuroblasts elicits postnatal NB formation. However, the normal function of Lin28B in the development of sympathetic neurons and chromaffin cells and the mechanisms involved in Lin28B-induced tumor formation are unclear. Here, we demonstrate a mirror-image expression of $\operatorname{Lin} 28 B$ and Let-7a in developing chick sympathetic ganglia. Lin $28 B$ expression is not restricted to undifferentiated progenitor cells but, is observed in proliferating noradrenergic neuroblasts. Lin 28 knockdown in cultured sympathetic neuroblasts decreases proliferation, whereas Let-7 inhibition increases the proportion of neuroblasts in the cell cycle. Lin28B overexpression enhances proliferation, but only during a short developmental period, and it does not reduce Let-7a. Effects of in vivo Lin $28 B$ overexpression were analyzed in the LSL-Lin $28 B^{D B H i C r e}$ mouse line. Sympathetic ganglion and adrenal medulla volume and the expression level of Let-7a were not altered, although Lin $28 B$ expression increased by 12 - to 17 -fold. In contrast, Let-7a expression was strongly reduced in LSL-Lin $28 B^{D b h i C r e} \mathrm{NB}$ tumor tissue. These data demonstrate essential functions for endogenous $\operatorname{Lin} 28$ and Let-7 in neuroblast proliferation. However, Lin $28 B$ overexpression neither sustains neuroblast proliferation nor affects let-7 expression. Thus, in contrast to other pediatric tumors, Lin $28 B$-induced NB is not due to expansion of proliferating embryonic neuroblasts, and Let-7-independent functions are implicated during initial NB development.

Key words: Let-7; Lin28; neuroblastoma; neurogenesis; proliferation; sympathetic

Significance Statement

Lin28A/B proteins are highly expressed in early development and maintain progenitor cells by blocking the biogenesis and differentiation function of Let-7 microRNAs. Lin28B is aberrantly upregulated in the childhood tumor neuroblastoma (NB). NB develops in sympathetic ganglia and adrenal medulla and is elicited by forced Lin $28 \mathrm{~B}$ expression. We demonstrate that Lin28A/B and Let-7 are essential for sympathetic neuroblast proliferation during normal development. Unexpectedly, Lin28B upregulation in a mouse model does not affect neuroblast proliferation, ganglion size, and Let-7 expression during early postnatal development. Lin28B-induced NB, in contrast to other pediatric cancers, does not evolve from neuroblasts that continue to divide and involves Let-7-independent functions during initial development.

\section{Introduction}

Neuroblastoma (NB) is a childhood cancer that arises from cells of the developing sympathetic nervous system, and primary tu-

Received July 6, 2015; revised Nov. 4, 2015; accepted Nov. 10, 2015.

Author contributions: M.H., J.S., U.E., and H.R. designed research; M.H., J.S., I.A.-E.M., M.K., and C.P.-E. performed research; I.J.-L., 0.D., and J.B.S. contributed unpublished reagents/analytic tools; M.H., J.S., I.A.-E.M., M.K., T.D., and H.R. analyzed data; M.H., J.S., T.D., I.J.-L., U.E., and H.R. wrote the paper. mors are located in sympathetic ganglia and adrenal glands. NB presents a broad clinical spectrum, but aggressive metastatic tumors (S4)represent the majority of NB cases in older children, are still largely incurable, and account for about $10 \%$ of pediatric cancer-related deaths (Maris et al., 2007).

This work was supported by grants from the Wilhelm Sander Foundation to H.R. We thank Melanie Bickel and Sabine Stanzel for excellent technical assistance and Julia Holzmann for comments on this manuscript. 
Previous studies provided evidence for a role of the $\operatorname{Lin} 28 B$ gene in NB development. Genomic variations [small nucleotide polymorphisms (SNPs)] in the Lin28B gene influence susceptibility to NB development, and Lin $28 B$ expression levels are elevated in aggressive forms of $\mathrm{NB}$ and correlate with poor prognosis (Diskin et al., 2012). Association of Lin28B with advanced disease and poor clinical outcome has been demonstrated also for other tumor types, including pediatric cancers (Viswanathan et al., 2009; Zhou et al., 2013; Urbach et al., 2014). Lin28B emerged as an oncogenic driver for NB since forced expression of Lin28B in sympathoadrenal cells is sufficient to induce tumors with the gene expression pattern (Dbh, Th, Phox $2 a, M Y C N$ ) characteristic for NB in postnatal sympathetic ganglia and adrenals (Molenaar et al., 2012). Because the normal function of Lin28B during sympathetic nervous system development is not known, it remains unclear why sympathoadrenal cells are susceptible to genomic variations in the $\operatorname{Lin} 28 B$ gene and how $\operatorname{Lin} 28 B$ overexpression causes NB.

The RNA-binding proteins Lin28B and Lin28A (collectively called Lin28) are expressed in stem and progenitor cells and have essential functions in the maintenance of stem cell identity (Thornton and Gregory, 2012). The Lin 28 proteins inhibit the biogenesis of Let-7 family microRNAs, thereby interfering with progenitor differentiation and promoting stem cell growth. Conversely, Lin28 expression is antagonized by Let-7. This inverse regulatory relationship is well documented for stem cells in developing and tumor tissues (Viswanathan et al., 2009; Thornton and Gregory, 2012), but is also important for the timing of neuron production during nervous system development (La Torre et al., 2013). Let-7 expression increases during neuron differentiation, and Let-7 overexpression interferes with proliferation and elicits differentiation of neural stem cells in the mouse brain (Wulczyn et al., 2007; Rybak et al., 2008; Schwamborn et al., 2009; Zhao et al., 2010; La Torre et al., 2013). Lin28 and Let-7, discovered in Caenorhabditis elegans as heterochronic genes that control cell fate succession, may thus have similar functions in the developing vertebrate nervous system (Balzer et al., 2010; La Torre et al., 2013). Although Let-7-suppression accounts for many Lin28 effects, Lin28 also binds and influences the translation of a large number of messenger RNAs, and Let-7-independent functions for Lin28B were described previously during brain and tumor development (Hafner et al., 2013; Nguyen et al., 2014; Yang et al., 2015).

In contrast to other lineages in the central and peripheral nervous system, neuron differentiation in sympathetic ganglia is not linked to cell cycle withdrawal (Rohrer, 2011). Neurogenesis proceeds mainly by proliferation of immature but already differentiated noradrenergic neuroblasts (Rothman et al., 1978; Rohrer and Thoenen, 1987). Undifferentiated progenitor cells are present only at the onset of neurogenesis (Tsarovina et al., 2008; Gonsalvez et al., 2013). Lin28B overexpression in embryonic sympathoadrenal cells elicits tumor formation in sympathetic ganglia and adrenal medulla (Molenaar et al., 2012). It was unclear, however, whether the timing and differentiation of sympathetic neuron development are controlled by endogenous Lin28 and Let-7 and whether forced Lin28B expression leads to tumor initiation by interfering with terminal differentiation, as

\section{The authors declare no competing financial interests.}

Correspondence should be addressed to Hermann Rohrer, Institute of Clinical Neuroanatomy, Goethe University Frankfurt/M, Theodor-Stern-Kai 7, 60590 Frankfurt am Main, Germany. E-mail: hermann.rohrer@brain.mpg.de. DOI:10.1523/JNEUROSCI.2560-15.2015

Copyright $\odot 2015$ the authors $\quad 0270-6474 / 15 / 3516532-14 \$ 15.00 / 0$ observed for other types of pediatric tumors (Viswanathan et al., 2009; Gillis et al., 2011; Urbach et al., 2014).

Here, we demonstrate essential functions for endogenous Lin28A/B and Let-7 in sympathetic neuroblast proliferation. However, Let-7a expression is not affected in vitro and in vivo by $\operatorname{Lin} 28 B$ overexpression, and postnatal ganglia and adrenal medulla show normal size and differentiation in the LSLLin $28 B^{\text {DbhiCre }}$ mouse. Thus, in contrast to other pediatric cancers, Lin28B-induced NB development is not caused by a failure to differentiate and leave the cell cycle.

\section{Materials and Methods}

Transfection and culture of sympathetic ganglion cells. Sympathetic ganglia (SGs) from embryonic day 6.5 (E6.5) to E12 chicken embryos were dissected and dissociated by the use of $0.1 \%(\mathrm{w} / \mathrm{v})$ trypsin as described previously (Rohrer and Thoenen, 1987; Zackenfels et al., 1995). Single cell suspensions were electroporated with the Amaxa Basic Neuron Small Cell Number (SCN) Nucleofector Kit (Program SCN 4). The following concentrations of DNA or RNA were used: pCAGGSggLin28B $(0.5 \mu \mathrm{g} /$ $300,000$ cells $)$, pmaxGFP Vector $(0.25 \mu \mathrm{g} / 300,000$ cells $)$, and empty pCAGGS vector $(0.5 \mu \mathrm{g} / 300,000$ cells $)$ as control; miRCURYLNA Power family inhibitor hsa-let7 (10 pmol/200,000 cells; Exiqon) and, as control, miRCURYLNA inhibitor negative control B (30 pmol/200,000 cells; Exiqon); iBONI siRNA Quattro siggLin28A or B (50 pmol from each siRNA/300,000 cells; Riboxx) and, as control, iBONI siRNA Negative Control-N1 (200 pmol/300,000 cells; Riboxx); sensor mRNA Let7a and miR-1 (10 pmol/200,000 cells). After density step-gradient centrifugation to remove cell debris, 15,000 cells per well were plated on four-well culture dishes coated with $0.5 \mathrm{mg} / \mathrm{ml}$ poly-DL-ornithine (Sigma) in $0.15 \mathrm{M}$ borate buffer, $\mathrm{pH} 8.3$, and $10 \mu \mathrm{g} / \mathrm{ml} \mathrm{laminin}$ (Invitrogen) in PBS, $\mathrm{pH} 7.3$, and cultured in MEM, $1 \%(\mathrm{w} / \mathrm{v})$ penicillin/streptomycin, $1 \%(\mathrm{w} / \mathrm{v}) \mathrm{glu}-$ tamine, $10 \%(\mathrm{v} / \mathrm{v})$ horse serum, and $5 \%(\mathrm{v} / \mathrm{v})$ fetal calf serum (SG medium) for $2 \mathrm{~d}$. Proliferating cells were detected by 5 -ethinyl-2' desoxyuridine (EdU) labeling using the Click-iT EdU Alexa Fluor 488 or 594 imaging kit (Invitrogen) as described previously (Reiff et al., 2011; Holzmann et al., 2015). The proportion of EdU-labeled neurons was quantified in at least three independent experiments and statistically analyzed using two-tailed Student's $t$ test.

Detection of Let-7 and miR-1 expression by RNA sensor. To generate Let-7 and miR-1 sensor mRNA for transfection, a pSLU plasmid was used (kind gift from A. La Torre and T. Reh, University of Washington, Seattle, WA). To synthesize the sensor mRNA we used mMESSAGE mMACHINE T7 Ultra Kit from Ambion according to the manufacturer's instructions. To detect GFP, expressed by the Let-7 or mir-1 sensor mRNA, an immunostaining for GFP was performed. Cells were fixed with $4 \%(\mathrm{w} / \mathrm{v})$ paraformaldehyde for $15 \mathrm{~min}$, permeabilized with $0.25 \%$ $(\mathrm{w} / \mathrm{v})$ Triton X-100 (AppliChem) in PBS, washed twice with PBS, and blocked with $5 \%(\mathrm{v} / \mathrm{v})$ goat serum in PBS for at least $1 \mathrm{~h}$. The primary antibody against GFP (rb IgG polyclonal; Invitrogen; 1:400 in PBS) was incubated at RT for $1 \mathrm{~h}$. After washing twice with PBS, the cells were incubated with Alexa 594-labeled secondary antibody (1:500; Invitrogen). Nuclei were stained by DAPI (Sanofi). The number of GFPnegative cells was quantified using a Zeiss Axiophot2 microscope in combination with a Visitron systems spot RT3 camera. Experiments were repeated independently at least three times and statistically analyzed using unpaired two-tailed Student's $t$ test.

In situ hybridization. Chick embryos were staged according to Hamburger and Hamilton (1951) and fixed in 4\% (w/v) paraformaldehyde in $0.1 \mathrm{~m}$ sodium phosphate buffer, $\mathrm{pH} 7.3$, for $3 \mathrm{~h}$ or overnight, depending on the Hamburger-Hamilton (HH) stage. Embryos were subsequently dehydrated in $15 \%(\mathrm{w} / \mathrm{v})$ sucrose in $0.1 \mathrm{M}$ sodium phosphate buffer, $\mathrm{pH}$ 7.3. Whole embryos were embedded in Tissue Tec (Sakura Fintek), and cryosections of $12 \mu \mathrm{m}$ from the brachial region were prepared for in situ hybridization. Riboprobes were synthesized from linearized plasmids by the use of a DIG RNA Labeling Kit (Roche) according to manufacturer's instructions. The following cRNA probes were used: SCG10 (890 bp; ggSCG10 kindly provided by A. Groves, Caltech, Pasadena, CA), ggNotch1 (4 kb; Wakamatsu et al., 2000), ggLin28A (738 bp, correspond- 


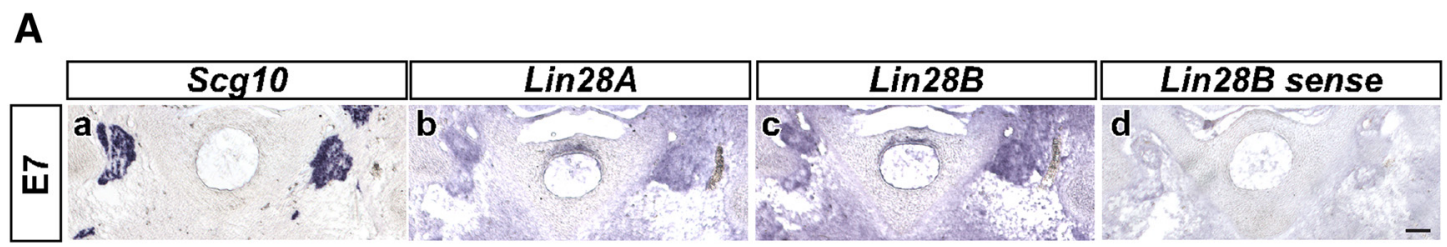

B

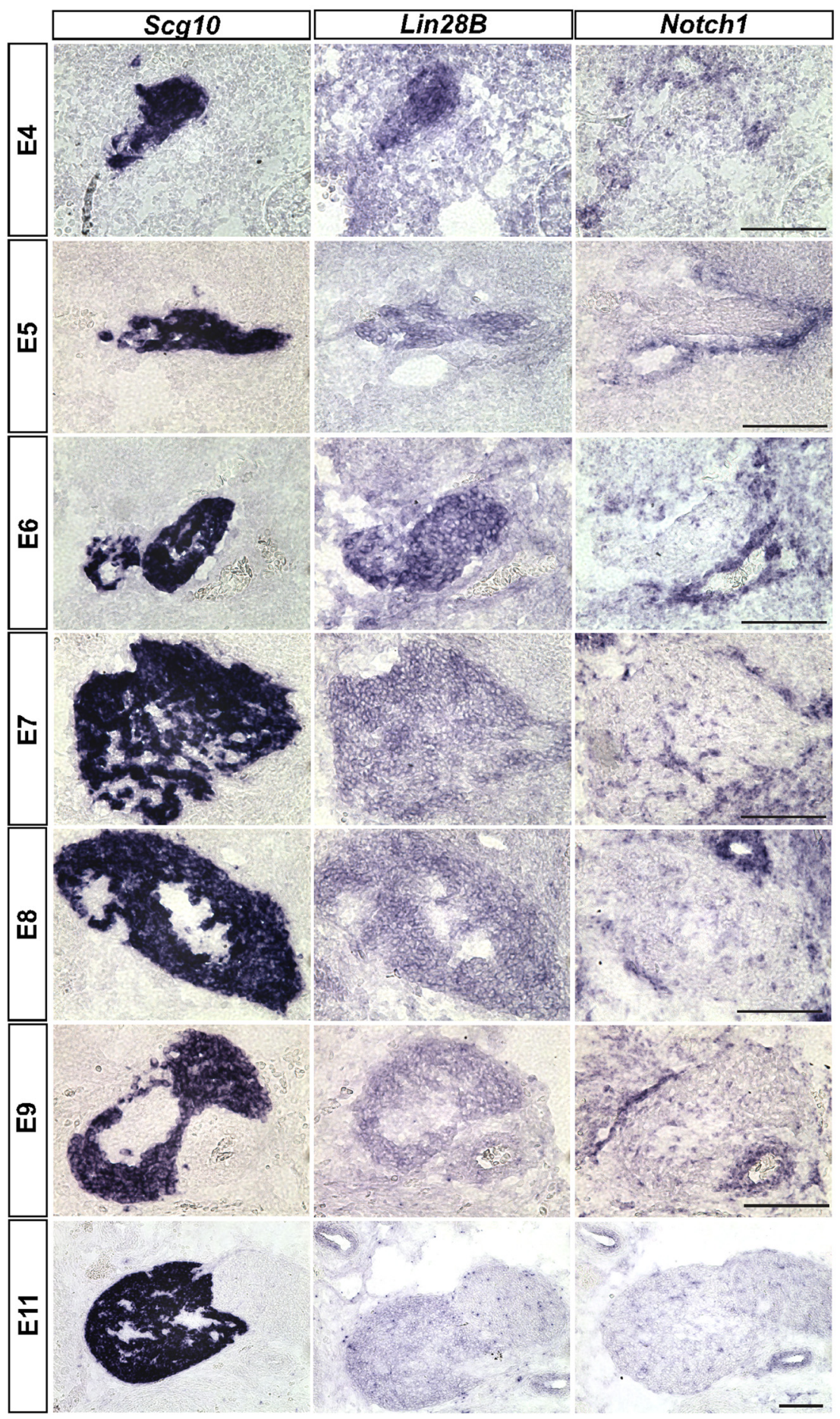

Figure 1. Lin28B expression in developing chick sympathetic ganglia. $A$, Lin28A and Lin28B are coexpressed in sympathetic ganglia at E7. Parallel sections were stained for the neuronal marker SCG10 to identify the ganglion location. $\boldsymbol{B}$, The expression of $L i n 28 B$ was analyzed by in situ hybridization on frozen sections of E4-E11 chick embryos. SCG10 was used to identify the ganglion location. Notch 1 was used as marker for sympathetic progenitors. Lin28B is broadly expressed throughout the ganglia. The Lin28B hybridization signal decreases between E7 and E11. Scale bars, $100 \mu \mathrm{m}$. 


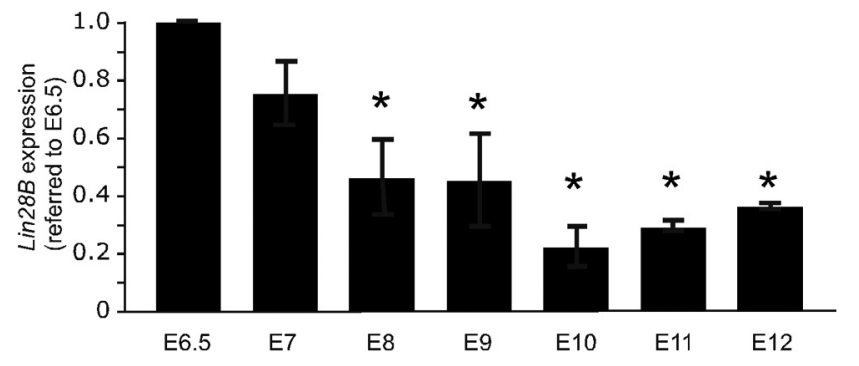

Figure 2. Analysis of $L$ in $28 B$ expression in developing chick sympathetic ganglia by qRTPCR. Lin28B mRNA expression was quantified by RT-qPCR at E6.5, E7, E8, E9, E10, E11, and E12 and normalized to Gapdh. Lin28B expression levels were significantly reduced from E8 onward compared to E6.5 levels (mean $\pm \mathrm{SEM} ; n=3$; statistical analysis by relative expression software REST). ${ }^{*} p<0.05$.

ing to base 444-1182 of NM_001031774), and ggLin28B (711 bp, corresponding to base 491-1201 of NM_001034818). PCR technology was used to amplify the coding sequence of $g g \operatorname{Lin} 28 B$ from chick E5 ciliary ganglia and to fuse in front the Kozak sequence of the src oncogene. The fusion product was ligated into the expression vector pCAGGS using additional SacI and SphI sites of the polylinker ( $g g L i n 28 B$ primer, sense, 5' -TTG AGC TCA CCA CCA TGG CCG AAG C-3'; antisense, 5' -TTG CAT GCT TAA GTT TTT TTC CTT TTC TGA ACA GAA GGC C-3'). Nonradioactive in situ hybridization (ISH) on cryosections was performed as described previously (Ernsberger et al., 1997) with the following modifications: hybridization was performed at $68^{\circ} \mathrm{C}$, the following washing step was done at $72^{\circ} \mathrm{C}$ for at least $1.5 \mathrm{~h}$. Sections were blocked for $2 \mathrm{~h}$, and the anti-DIG antibody was applied in a dilution of 1:4500. ISH on mouse tissues was performed as described previously (Stubbusch et al., 2014). The following cRNA probes were used: $m m P h o x 2 b$ (1604 bp), $m m D b h$ (987 bp; both kindly provided by J.-F. Brunet, Ecole Normale Superieure, Paris, France), and $m m N f-m$ (680 bp, corresponding to base 2468-3147 of NM_008691). Images were taken using a Zeiss Axiophot2 microscope in combination with a Visitron systems spot RT3 camera, adapted for brightness and assembled in Photoshop.

For morphometric analysis, the area of $D b h, P h o x 2 b$, and $N f-m$ expression was imaged at $20 \times$ magnification. The areas were quantified using the MetaVue (version 7.1.3.0) imaging system. The stained areas were manually thresholded and quantified as square millimeters per section. The mean volume of ganglia and adrenal medulla was calculated using the Cavalieri principle (Gundersen et al., 1988). For statistical analysis unpaired two-tailed Student's $t$ test was used.

$q R T-P C R$ analysis. For expression analysis of Lin28B and the miRNA Let-7a, sympathetic ganglia from chicken embryos E6.5 to E12 were dissected, and RNA was isolated using the RNeasy Kit (Qiagen) for Lin28B and the miRNeasy Kit (Qiagen) for Let-7a, following the manufacturer's instructions. For the transcription of RNA into cDNA the SuperScript III reverse transcriptase (Invitrogen) was used for $\operatorname{Lin} 28 B$, and the miScript II RT Kit (Qiagen) for Let-7a. For qPCR experiments of transfected neuroblasts, cells were plated on poly-DL-ornithine/laminin-coated $3.5 \mathrm{~cm}$ culture dishes in SG medium. After 2 d of cultivation, the cells were scraped off, and RNA/miRNA was isolated as described for dissected ganglia. qPCR experiments were performed using the QuantiTect SYBR Green PCR Kit with the following QuantiTect primer assays (Qiagen): Gg_Lin28B_1_SG, Gg_Prox1_1_SG, Gg_Ntrk1_1_SG, Gg_Tfap2a _1_SG, Gg_Ascl1_1_SG, and Gg_Gapdh_1_SG. For quantification of the miRNA Let-7a, the miScript SYBR Green PCR Kit in combination with miScript primer assays (Qiagen) for Let-7a (Mm_let7a_2) and RNU (Hs_RNU6-2_11) was used. The temperature profile for all qPCR experiments was the following: $95^{\circ} \mathrm{C}$ for $15 \mathrm{~min}$ and 40 cycles $\left(94^{\circ} \mathrm{C}\right.$ for $15 \mathrm{~s}, 55^{\circ} \mathrm{C}$ for $30 \mathrm{~s}, 72^{\circ} \mathrm{C}$ for $30 \mathrm{~s}$ ). The primer pairs were analyzed for efficiency $(>95 \%)$. At least triplets of every condition were performed in parallel. Data were normalized to Gapdh (mRNA) or RNU6(miRNA) as reference genes and evaluated using the $\Delta \Delta C_{\mathrm{t}}$ method. Experiments were repeated independently at least three times and analyzed statistically using the pairwise fixed reallocation randomization test of relative expression software tool (REST; Pfaffl et al., 2002). For expression analysis of $\operatorname{Lin} 28 B$ and the miRNA Let-7a in mouse tissues, the same protocol was followed using the QuantiTect primer assays (Qiagen) Mm_Lin28b_1_SG and Mm_Gapdh_3_SG. Superior cervical ganglia (SCGs), stellate ganglia (STGs), and adrenal glands were dissected from postnatal day 0 (P0), P15-P20, and P60 mice as indicated. Tumors located at the adrenal gland or at the paravertebral sympathetic chain were dissected from P60-P100 mice.

Mice. LSL-Lin28B mice (Molenaar et al., 2012) and Dbh-iCre mice (Stanke et al., 2006; Parlato et al., 2007) have been described previously. LSL-Lin $28 B$ and Dbh-iCre mice backcrossed to $129 \mathrm{X} 1 / \mathrm{SvJ}$ mice (Jackson Laboratory) were used. $L S L$-Lin $28 B$ mice were kept homozygous for the floxed $L S L$-Lin $28 B$ allele and crossed with heterozygous Dbh-iCre mice carrying an iCre recombinase transgene under control of the dopamine $\beta$-hydroxylase $(D b h)$ promoter, resulting in double-transgenic $L S L$ Lin28B ${ }^{\text {DbhiCre }}$ mice. LSL-Lin28B mice are used as controls. TH-MYCN mice backcrossed to 129/S2 were used (Weiss et al., 1997). Day of birth was counted as P0.

Dissection and fixation conditions for mouse tissues. For in situ hybridization and immunohistochemistry, P20 SCGs and adrenal glands dissected with adjacent connective tissue from mice of either sex were fixed with $4 \%(\mathrm{w} / \mathrm{v})$ paraformaldehyde in $0.1 \mathrm{M}$ sodium phosphate buffer, $\mathrm{pH}$ 7.4 , at $4^{\circ} \mathrm{C}$ for $24 \mathrm{~h}$. P0 mice, after removing the intestine, were fixed under the same conditions. Fixative was replaced by $30 \%(\mathrm{w} / \mathrm{v})$ sucrose in $0.1 \mathrm{~m}$ sodium phosphate buffer, $\mathrm{pH} 7.4$, for $24 \mathrm{~h}$. Tissues were frozen in Tissue Tek (Sakura Finetek) and stored at $-20^{\circ} \mathrm{C}$. P22 STGs from $L S L$ Lin28B mice and P20 SCGs from TH-MYCN mice for Phox2b/Th and Ki67/Th double staining were embedded in Tissue Tek and frozen immediately after dissection. Twelve micrometer serial frozen sections were cut on a Leica CM3050 S cryostat. For RNA isolation, SCGs, STGs, and adrenal glands were dissected at P0 and P15-P19 and cleaned from connective tissue using a Leica Stereomicroscope.

Immunostaining. For immunostaining of mouse tissues, cryosections of either paraformaldehyde-fixed or unfixed tissues were used. Unfixed cryosections were postfixed with $4 \%$ paraformaldehyde $(\mathrm{w} / \mathrm{v})$ in $0.1 \mathrm{M}$ sodium phosphate buffer, $\mathrm{pH}$ 7.4, at RT for $25 \mathrm{~min}$. Fixed and postfixed cryosections were washed with PBS, followed by antigen retrieval by treating the sections with $100 \mathrm{~mm}$ sodium citrate, $\mathrm{pH} 6.0$, at $95^{\circ} \mathrm{C}$ for 30 min. Sections were washed in $\mathrm{H}_{2} \mathrm{O}$ and PBS. For Ki67/Th double staining, sections were incubated in PBS/0.1\% Triton X-100 (w/v) for $10 \mathrm{~min}$ followed by washing steps with PBS. Blocking was performed with $\mathrm{PBS} / 5 \% \mathrm{FCS}(\mathrm{v} / \mathrm{v}) / 1 \% \mathrm{BSA}(\mathrm{w} / \mathrm{v})$ for $60 \mathrm{~min}$. The primary antibodies rat anti-mouse Ki-67 (BioLegend, clone 16A8, catalog \#652402, 1:200), mouse anti-Th (1:100; Rohrer et al., 1986) and mouse anti-Islet1 (1:40) were diluted in blocking solution. The anti-Islet 1 antibody 39.4D5 developed by T. Jessell (Columbia University, New York) was obtained from the Developmental Studies Hybridoma bank developed under the auspices of the NICHD and maintained by the University of Iowa Department of Biology (Iowa City, Iowa). Sections were incubated overnight at $4^{\circ} \mathrm{C}$. After washing in PBS, Alexa 488 goat anti-mouse and Alexa 546 goat anti-rat antibodies were used as secondary antibodies. For detection of Phox $2 \mathrm{~b}$ sections were blocked with PBS/10\% FCS (v/v)/1\% BSA (w/v)/ $0.1 \%$ Triton X-100 (w/v) after antigen retrieval. The primary antibodies rabbit anti-mouse Phox2b (Pattyn et al., 1997) and mouse anti-Th (Rohrer et al., 1986) were used at 1:1000 and 1:100, respectively, in blocking solution. After washing in PBS/0.1\% Triton X-100 (w/v), Alexa 488conjugated goat anti-mouse and Alexa 594-conjugated goat anti-rabbit antibodies were used as secondary antibodies.

\section{Results}

\section{Expression of Lin28B and Let-7 during sympathetic neuron development}

The expression and function of Lin $28 B$ and Let-7 during neuron generation was initially studied using embryonic stem (ES) cells and P19 embryocarcinoma (EC) cells induced to neuron differentiation (Wulczyn et al., 2007; Rybak et al., 2008). In these cells, Let-7 expression is absent at the stem cell stage and is rapidly induced in differentiating neurons. Lin 28 shows a mirror image expression; i.e., it is present in ES and EC cells and decreases during differentiation. Neural stem and progenitor cells, in con- 
A

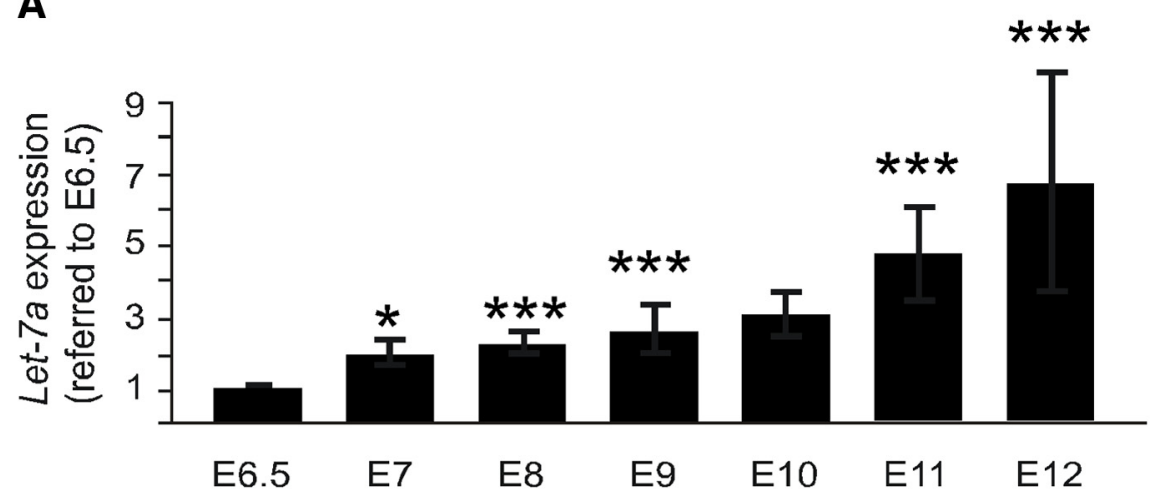

B

Let-7 sensor Mir-1 sensor

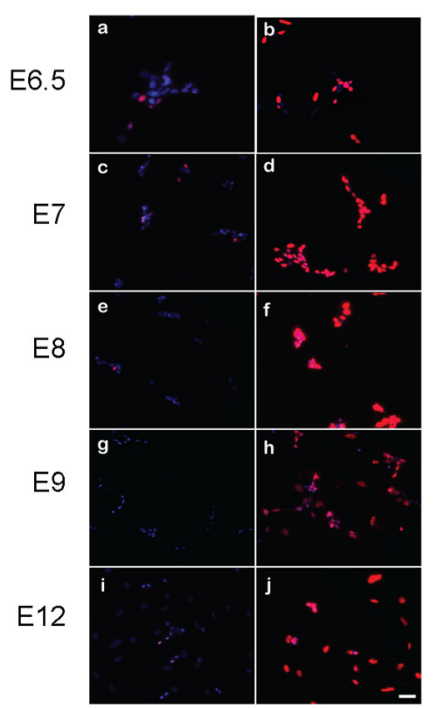

C

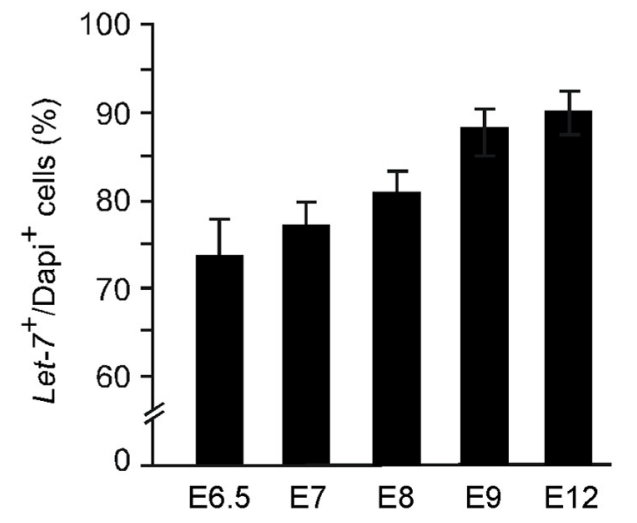

Figure 3. Analysis of Let-7a expression in developing chick sympathetic ganglia by qRT-PCR and by a Let-7 sensor. A, Expression of mature Let-7 miRNA (normalized to RNU6) was quantified by qRT-PCR, using stem-loop primers. Let-7a expression levels were significantly increased from E8 onward compared to E6.5 levels (mean $\pm \mathrm{SEM} ; n=3$; statistical analysis by relative expression software REST). ${ }^{*} p<0.05 ;{ }^{* * *} p<0.001 . B, C$, To determine Let-7 expression at the single-cell level, freshly dissociated sympathetic ganglion cells were transfected with Let-7 sensor RNA and Mir- 7 sensor RNA as control. We found that $75 \pm 5 \%$ (mean \pm SEM; $n=3$ ) of transfected E6.5 sympathetic neuroblasts express Let-7, which is reflected by the degradation of the Let-7 sensor RNA. Scale bar, $30 \mu \mathrm{m}$. C, The percentage of Let-7-expressing cells increases with development, reaching $90 \pm 2 \%$ (mean \pm SEM; $n=3)$ at E12. The data were corrected for the RNA transfection efficiency $(92 \pm 2.6 \%)$. The Mir- 1 sensor RNA is maintained, demonstrating that degradation of sensor RNA depends on the presence of miRNA.

trast, express both Let-7 and Lin28, and the developmental increase in Let-7 levels was shown to control the temporal identity of retinal progenitors (Rybak et al., 2008; La Torre et al., 2013). In differentiated neurons, Let-7 expression is maintained, but $\operatorname{Lin} 28$ expression is lost. During neurogenesis in sympathetic ganglia neural progenitor cells differentiate to neuroblasts expressing catecholaminergic and neuronal properties. Neuroblasts continue to proliferate, and postmitotic neurons are produced by neuroblast cell cycle withdrawal (Rohrer, 2011). The restriction of $\operatorname{Lin} 28$ expression to early progenitors in the retina (La Torre et al., 2013) suggested that $\operatorname{Lin} 28$ expression would be limited to sympathetic progenitor cells present in the chick model only up to E5 (Tsarovina et al., 2008). Interestingly, Lin28B expression was detected by in situ hybridization in sympathetic ganglia up to E11 (Fig. 1). Although expression was highest at E4-E6, it was not restricted to neuron progenitor cells identified by Notch 1 expression, but rather present throughout the ganglion neuroblast/neu- ron population identified by SCG10 expression (Fig. 1). Notably, also in the spinal cord, $\operatorname{Lin} 28 B$ expression is detectable in postmitotic neurons, most evident for motoneurons (data not shown). Similar expression patterns were observed for Lin28A in sympathetic ganglia and spinal cord (Fig. 1A; data not shown). The quantification of $\operatorname{Lin} 28 B$ in sympathetic ganglia by qRT-PCR demonstrates a significant decrease between E6.5, the earliest stage chick sympathetic ganglia can be dissected and E8 (Fig. 2). From E8 onward, the expression remains reduced, in the range of $20-40 \%$ of E6.5 levels.

Let-7 expression was followed using qRT-PCR for Let-7a, commonly used as a representative member of the Let-7 family (Viswanathan et al., 2009; Molenaar et al., 2012; Nguyen et al., 2014), and revealed a steady strong (sixfold) increase in Let-7a expression between E6.5 and E12 (Fig. $3 A$ ). This result may reflect an increase in the proportion of Let-7a-expressing cells or a general increase in Let-7a levels in sympathetic neuroblasts. To address this issue, Let-7 expression was analyzed at the cellular level using short-term cultures of sympathetic ganglion cells transfected with a Let-7 sensor (La Torre et al., 2013). The sensor consists of RNA coding for a fluorescent protein (GFP) and contains Let-7 binding sites in the 3 -terminal UTR. In the absence of Let-7, transfected cells produce a strong fluorescent signal, whereas sensor RNA interacting with Let-7 is rapidly degraded. At E6.5, when Let-7a levels are low (Fig. $3 A$ ), already $74 \pm 5 \%$ of sympathetic neuroblasts express sufficient amounts of Let-7 to degrade the sensor (Fig. $3 B, C$ ). The fraction of Let-7-expressing cells further increases and reaches $90 \pm 2 \%$ at E12. The miR-1 sensor, which was used as control because $m i R-1$ is not expressed in neurons, is not degraded (Fig. 3B). The increase in the fraction of Let-7-expressing cells cannot account for the sixfold increase in Let-7a levels, arguing for a general increase in Let-7a levels of sympathetic neuroblasts and neurons during development.

\section{Lin28A and Lin28B are crucial for sympathetic neuroblast proliferation}

The developmental changes in Lin28A/B and Let-7a expression levels do not correlate with the differentiation of sympathetic progenitor cells to noradrenergic neuroblasts, which terminates at E5 (Tsarovina et al., 2008), but are compatible with a function in neurogenesis, which extends between E3 and E12 in chick sympathetic ganglia (Rohrer, 2011; Holzmann et al., 2015). Maximal numbers of proliferating neuroblasts are present at E5-E7, decreasing to background levels at E12. To identify a role of $\operatorname{Lin} 28$ in the control of proliferation, sympathetic neuroblasts were transfected in vitro with specific siRNA directed against $\operatorname{Lin} 28 \mathrm{~A}$ and Lin28B. Cultured neuroblasts from E7, E8, and E9 sympa- 
thetic ganglia transfected with siLin $28 A$ and $\operatorname{siLin} 28 B$ display a strong reduction in the proportion of cells labeled with the S-phase marker EdU (Fig. 4A,B). The combined knockdown of both Lin28A and $\operatorname{Lin} 28 B$ did not further reduce proliferation, which is in agreement with a common target. These results demonstrate that Lin28A and Lin28B are important for the proliferation of sympathetic neurons and raise the questions of whether these effects may be due to reduced Let-7 expression and whether the developmental increase of Let-7 expression reflects an antiproliferative function.

\section{Let-7 knockdown increases sympathetic neuroblast proliferation}

To investigate the function of Let-7 in neuroblast proliferation, sympathetic ganglion cells were transfected with a Let-7 microRNA family inhibitor, which binds to and blocks all Let-7 family members (Frost and Olson, 2011). Interfering with Let-7 function increased neuroblast proliferation at E8 and E9, but did not quite reach significance at E7. The proportion of $\mathrm{EdU}^{+}$cells decreases in untreated controls from $43 \pm 1.8 \%$ at E7 to $30 \pm 2 \%$ at E8 and $25 \pm 1.2 \%$ at E9 (Fig. 5). Let-7 inhibition at E8 increased the proportion of $\mathrm{EdU}^{+}$cells to $41 \pm 2.9 \%$, comparable to the level observed in E7 controls. Similarly, at E9 the proportion of EdU ${ }^{+}$cells was increased upon Let-7 inhibition to $34 \pm 1.5 \%$, close to the level observed in E8 control. These results indicate that the developmental increase in Let-7 levels may contribute to the cell cycle withdrawal and termination of neurogenesis. The observation that the increase in proliferation elicited by Let-7 inhibition at E7 does not reach significance $(p=$ 0.06 ) suggests that the endogenous Let-7 levels observed at this stage (Fig. 3) are not quite sufficient to repress neuroblast proliferation, in contrast to those at E8 and E9.

\section{Lin $28 B$ overexpression increases sympathetic neuroblast proliferation}

Lin28 and Let-7 expression patterns and opposite functions of Lin28 and Let-7 in neuroblast proliferation are in agreement with the cross-regulatory expression of Lin 28 and Let-7 observed in other lineages (Viswanathan et al., 2009; Thornton and Gregory, 2012). To support this notion, the effect of Lin $28 B$ overexpression was also investigated. Interestingly, increased proliferation was elicited by forced Lin $28 B$ expression only in E8 sympathetic neuroblasts, but not when E7 or E9 neuroblasts were transfected (Fig. 6A). Notably, Let-7a levels were not significantly reduced by Lin $28 B$ overexpression at all developmental stages investigated (Fig. 6B). In addition, Let-7a expression was unaffected by Lin28A or Lin28B knockdown at E8 (Let-7a expression in Lin28A

B
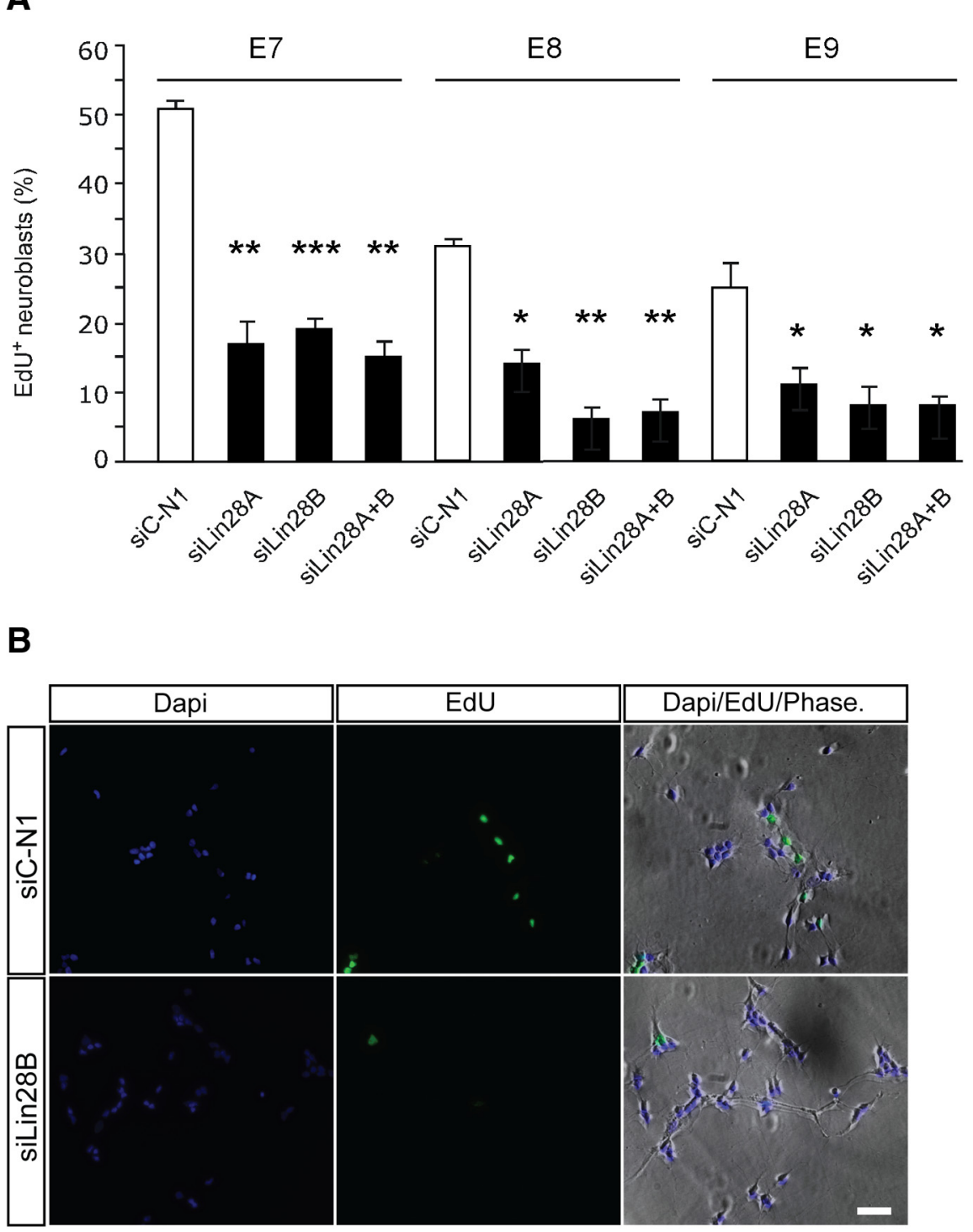

Figure 4. Proliferation of sympathetic neuroblasts depends on Lin28A and Lin28B. Freshly dissociated sympathetic ganglion cells from E7, E8, and E9 chick embryos were transfected with siRNA directed against Lin28A, Lin28B, or control N1 siRNA and staining, EdU-labeling, and combined DAPI, EdU, and phase contrast are shown to illustrate the reduced percentage of proliferating EdU ${ }^{+}$cells in cultures with Lin28B knockdown. Scale bar, $30 \mu \mathrm{m}$.

knockdown, $1.7 \pm 0.8$; in Lin28B knockdown, $1.16 \pm 0.15$ compared to controls; mean \pm SEM, $n=3-4)$. Thus, the proliferation effect in E8 neuroblasts cannot be explained by a selective effect on Let-7a expression. Developmental timing controlled by Lin 28 involves two separate pathways, only one of which involves Let-7 (Balzer et al., 2010; Vadla et al., 2012). To test the idea that Lin28B overexpression, although not reducing Let-7 levels, may affect the timing of neuroblast development, markers for sympathetic progenitors and early neuroblasts (Ascl1, AP-2a, Prox 1 ) and for more mature sympathetic neuroblasts and neurons (TrkA) were analyzed (Guillemot and Joyner, 1993; Von Holst et al., 1997; Schmidt et al., 2011; Holzmann et al., 2015). The expression levels of Ascl1, AP-2a, and TrkA are not changed by Lin28B overexpression, arguing against $\operatorname{Lin} 28 B$-induced dedifferentiation (Fig. 6C). The reduction in Prox 1, which is selectively 


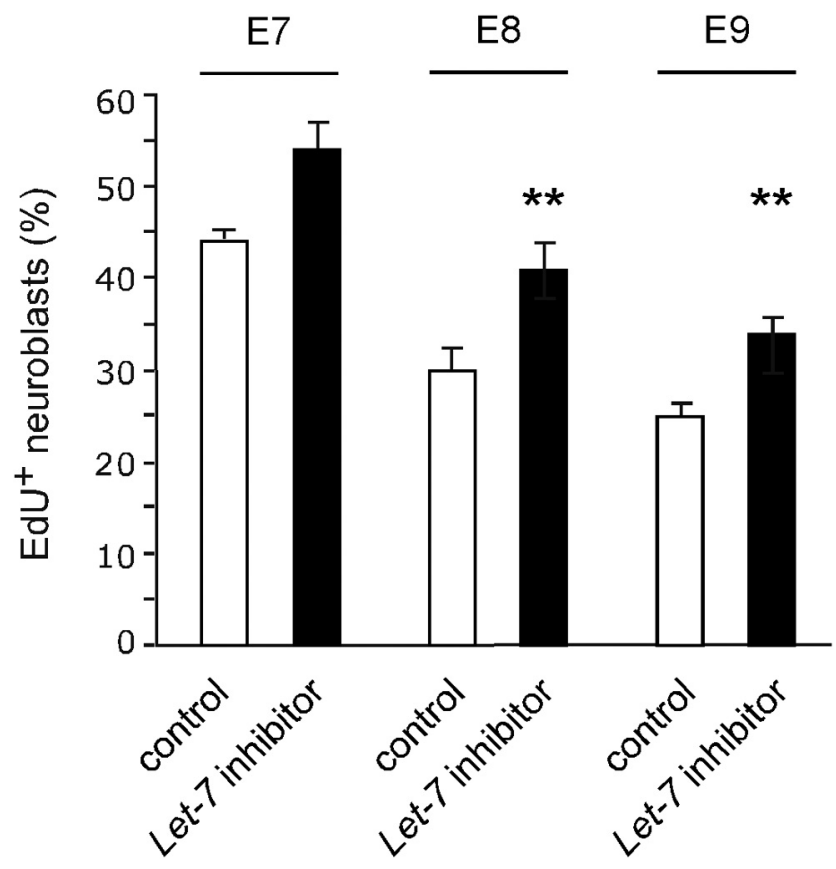

Figure 5. Proliferation of sympathetic neuroblasts is repressed by Let-7. Sympathetic ganglion cells from $\mathrm{E}$, E8, and $\mathrm{E9}$ chick embryos were treated with a Let-7 family inhibitor or a negative control inhibitor and analyzed for the proportion of EdU ${ }^{+}$proliferating cells after $2 \mathrm{~d}$ in culture. Let-7 inhibition results in significantly increased proliferation at E8 and E9. The increase observed at $\mathrm{E7}$ did not quite reach significance $(p=0.06$; mean $\pm \mathrm{SEM} ; n=3-4)$.

expressed in proliferating neuroblasts (Holzmann et al., 2015), may be explained by the decreased fraction of neuroblasts in the cell cycle.

In vivo effects of $\operatorname{Lin} 28 B$ overexpression in sympathetic ganglia and adrenals of the $L S L-L i n 28 B^{D B H i C r e}$ mouse line

To assess whether overexpression of $\operatorname{Lin} 28 B$ in noradrenergic cells can drive tumorigenesis, a transgenic mouse line was engineered in which $\operatorname{Lin} 28 B$ was introduced into the Rosa26 locus under the control of the $C M V / \beta$-actin promotor (Molenaar et al., 2012). Because $\operatorname{Lin} 28 B$ expression is prevented by a stop codon flanked by two loxP sites (LSL), these mice are termed $L S L$ Lin28B. LSL-Lin28B mice were crossed with DBHicre mice (Stanke et al., 2006; Parlato et al., 2007), and double-transgenic mice (Lin28B ${ }^{\text {DbhiCre }}$ ) were bred, expressing Lin $28 B$ in $D B H$ expressing cells as a result of stop codon elimination. Previous studies demonstrated that floxed genes are efficiently eliminated in sympathetic ganglia of DBHiCre mice at E11.5 (Parlato et al., 2007; Tsarovina et al., 2010; Majdazari et al., 2013). Lin28B ${ }^{\text {DbhiCre }}$ mice develop neuroblastoma with reduced Let-7 expression in ganglia and adrenals between postnatal day 35 and 66 (Molenaar et al., 2012). However, the initial effects of $\operatorname{Lin} 28 B$ overexpression on sympathetic neuroblast proliferation, Let-7 expression, and the development of precancerous stages are not known. To begin to address these issues, we first analyzed STG volume in $L S L$ Lin $28 B^{D B H i C r e}$ mice compared to LSL-Lin $28 B$ mice at P0. LSLLin $28 B$ tissues served as controls. Serial sections of P0 animals at the brachial region were processed for in situ hybridization using specific probes for Phox $2 b$, the general marker of the autonomic nervous system; for the noradrenergic marker $D b h$; and for the neuronal marker $N f-m$. Interestingly, the ganglion volume, determined from morphometric quantification of Phox $2 b$-stained ganglion areas, is not increased in $\operatorname{Lin} 28 B^{D B H i C r e}$ mice (Fig. $7 A, B)$. The expression levels of $D b h$ and $N f$ - $m$ are also unaffected
(Fig. $7 B$ ). The absence of morphological effects correlates with a normal level of Let-7a expression, although Lin $28 B$ is increased by about 12 -fold (Fig. $7 C, D$ ). The proportion of cycling neuroblasts is not increased in P0 STGs of LSL-Lin $28 B^{\text {DBHiCre }}$ mice as shown by Ki67 staining (Fig. 7 E, F). Thus, in vivo Lin $28 B$ overexpression does not affect Let-7a expression, ganglion size, and neuroblast proliferation in $\mathrm{P} 0$ sympathetic ganglia.

In the TH-MYCN NB mouse model, precancerous lesions significantly increase between $\mathrm{P} 0$ and $\mathrm{P} 14$ in prevertebral ganglia (Hansford et al., 2004; Alam et al., 2009). To test whether Lin28B overexpression also affects sympathetic ganglion development during this period, $L S L$-Lin $28 B^{\text {DbhiCre }}$ mice were analyzed at P15 and P20. However, also at this stage, sympathetic ganglia of $L S L$ Lin $28 B^{\text {DbhiCre }}$ and control mice display similar ganglion volume (Fig. 8A) and Let-7a expression levels (C), although Lin28B expression levels are 17-fold higher than in control ganglia $(B)$. Let-7a expression in sympathetic ganglia was maximally reduced to $30 \%$ in 1 out of 16 mice analyzed. Lin $28 B$ and Let-7a expression was also quantified in ganglionic tumors dissected from P60-P100 Lin $28 B^{\text {DBHiCre }}$ mice. In contrast to postnatal ganglia, Let-7a levels are massively reduced in Lin $28 B$-induced ganglionic tumors compared to adult sympathetic ganglia from P60 LSLLin $28 B$ control mice (Fig. 8E). Lin28B expression levels are increased 26-fold (Fig. 8D).

The majority of primary human NB is located in the adrenal (Brodeur, 2003), and this pattern is recapitulated in LSLLin28B ${ }^{\text {DBHiCre }}$ mice (Molenaar et al., 2012). Thus, it was of interest to investigate adrenal medulla size and Lin $28 B$ and Let-7 expression during postnatal development in $L S L-L i n 28 B^{D B H i C r e}$ mice and for comparison in LSL-Lin $28 B^{D B H i C r e}$ adrenal tumors. The adrenal medulla volume, determined from $D b h$-stained serial sections, was slightly increased at P0, but not at P20 (Fig. $9 A-C)$. Similar to sympathetic ganglia, Lin $28 B$ was increased (Fig. 9D), but Let-7a expression was not affected in adrenals at P15 (Fig. 9E), but strongly reduced in adrenal tumors $(G)$, which correlated with the very high Lin28B levels $(F)$.

Together, these data demonstrate that elevation of Lin $28 B$ levels in $D B H$-expressing sympathetic neuroblasts and chromaffin cells neither affect Let-7 expression nor tissue size and cell proliferation up to 2 weeks postnatally. In contrast, tumors that develop later in ganglia and adrenals display strongly reduced Let-7a levels and are highly proliferative (Molenaar et al., 2012; present findings).

Proliferation effects of $\operatorname{Lin} 28 B$ overexpression in sympathetic ganglia and adrenals of the $L S L-L i n 28 B^{D B H i C r e}$ mouse line

The strong difference in Let-7a expression observed between Lin28B-overexpressing P0-P20 sympathetic neurons and primary NB at ganglionic and adrenal locations may be explained by tumor initiation after P20 or by Lin28B-induced Let-7 knockdown and proliferation in a small number of neuroblasts that remain undetected in our analysis. The latter scenario is realized in the TH-MYCN mouse where clusters of proliferating Phox $2 \mathrm{~b}^{+} / \mathrm{TH}^{-}$neuroblasts are present in $\mathrm{P} 0$ ganglia of control and $T H-M Y C N$ mice in similar numbers, but are selectively maintained in MYCN-expressing ganglia (Hansford et al., 2004; Alam et al., 2009). Using double immunostaining for Phox $2 \mathrm{~b}$ and Th, we now demonstrate clusters of Phox $2 b^{+}$neuroblasts in SCGs of both $L S L-L i n 28 B^{D B H i C r e}$ and LSL-Lin $28 B$ controls at P0 (Fig. 10A). However, at P20, such cells are no more present in Lin $28 B$ overexpressing ganglia (Fig. $10 B a-B d ; n=10$ ) and control ganglia ( $n=3$; data not shown). Sympathetic ganglia of P22 $L S L-L i n 28 B^{D B H i C r e}$ mice were also devoid of clusters of prolifer- 
ating $\mathrm{Ki}^{+} 7^{+}$neuroblasts (Fig. $10 \mathrm{Ca}-\mathrm{Cd}$; $n=8)$. In contrast, clusters of cells with high Phox2b expression (Fig. 10Be-Bh) and $\mathrm{Ki}^{+}{ }^{+}$cell clusters (Fig. 10, Ce-Ch) are readily detected at $\mathrm{P} 20$ in $T H-M Y C N$ mice. This suggests that tumor initiation in $\operatorname{Lin} 28 B^{\text {DbhiCre }}$ mice differs from that in the TH-MYCN mouse model and does not involve the maintenance of proliferating precancerous cells.

\section{Discussion}

Forced expression of Lin $28 B$ in embryonic sympathetic neuroblasts results in NB that display reduced Let-7 levels (Molenaar et al., 2012). Maintained proliferation of mouse JoMal neuroblasts in response to $\operatorname{Lin} 28 B$ overexpression suggested that NB evolves from the expansion of neuroblasts that fail to leave the cell cycle (Molenaar et al., 2012). We now document the expression of $\operatorname{Lin} 28 A / B$ and Let-7a during neurogenesis in chick sympathetic ganglia and demonstrate that neuroblast proliferation is maintained by Lin28A/B and repressed by Let-7. Unexpectedly, forced Lin $28 B$ expression does not affect Let-7a and has limited proliferation effects in cultured neuroblasts. Also in the Lin28B-overexpressing $L S L$ Lin $28 B^{D B H i C r e}$ mouse line, sympathetic ganglia and adrenal medulla size and proliferation are not increased up to P20 and show normal Let-7a levels. These present findings demonstrate that NB does not evolve from expanding proliferating neuroblasts with reduced Let-7 expression. Lin28B-induced tumor formation seems to require cooperation with additional signals activated in tumor founder cells at late postnatal stages.

\section{Lin28A/B and Let-7 expression in developing sympathetic ganglia} $\operatorname{Lin} 28 A$ and $\operatorname{Lin} 28 B$ are expressed in a variety of developing tissues, including the nervous system. In the mouse neural tube, $\operatorname{Lin} 28 \mathrm{~A}$ is coexpressed with Sox2 at E9.5, but is lost at E10.5, although neural progenitor cells are present up to E13.5 (Helms and Johnson, 2003; Balzer et al., 2010). In the mouse retina, $\operatorname{Lin} 28 B$ is transiently expressed in early progenitors, and in cerebral cortex, overlapping expression of Lin $28 \mathrm{~A}$ and $\operatorname{Lin} 28 B$ was observed in nestin- and Pax6-expressing neural progenitor cells of the ventricular/subventricular zone (La Torre et al., 2013; Yang et al., 2015). In chick sympathetic ganglia, $\operatorname{Lin} 28 A$ and $\operatorname{Lin} 28 B$ expression is not restricted to progenitor cells, identified by Notch1 expression (Tsarovina et al., 2008), but is also present in differentiated neuroblasts and maintained at reduced levels in postmitotic neurons. Low-level expression of Lin28A/B in differentiated neurons has been detected in rat and zebrafish spinal cord (Ramachandran et al., 2010; Yue et al., 2014). Notably, Lin28 expression is also maintained in a number of differentiated tissues such as cardiac and skeletal muscle (Yang and Moss, 2003).
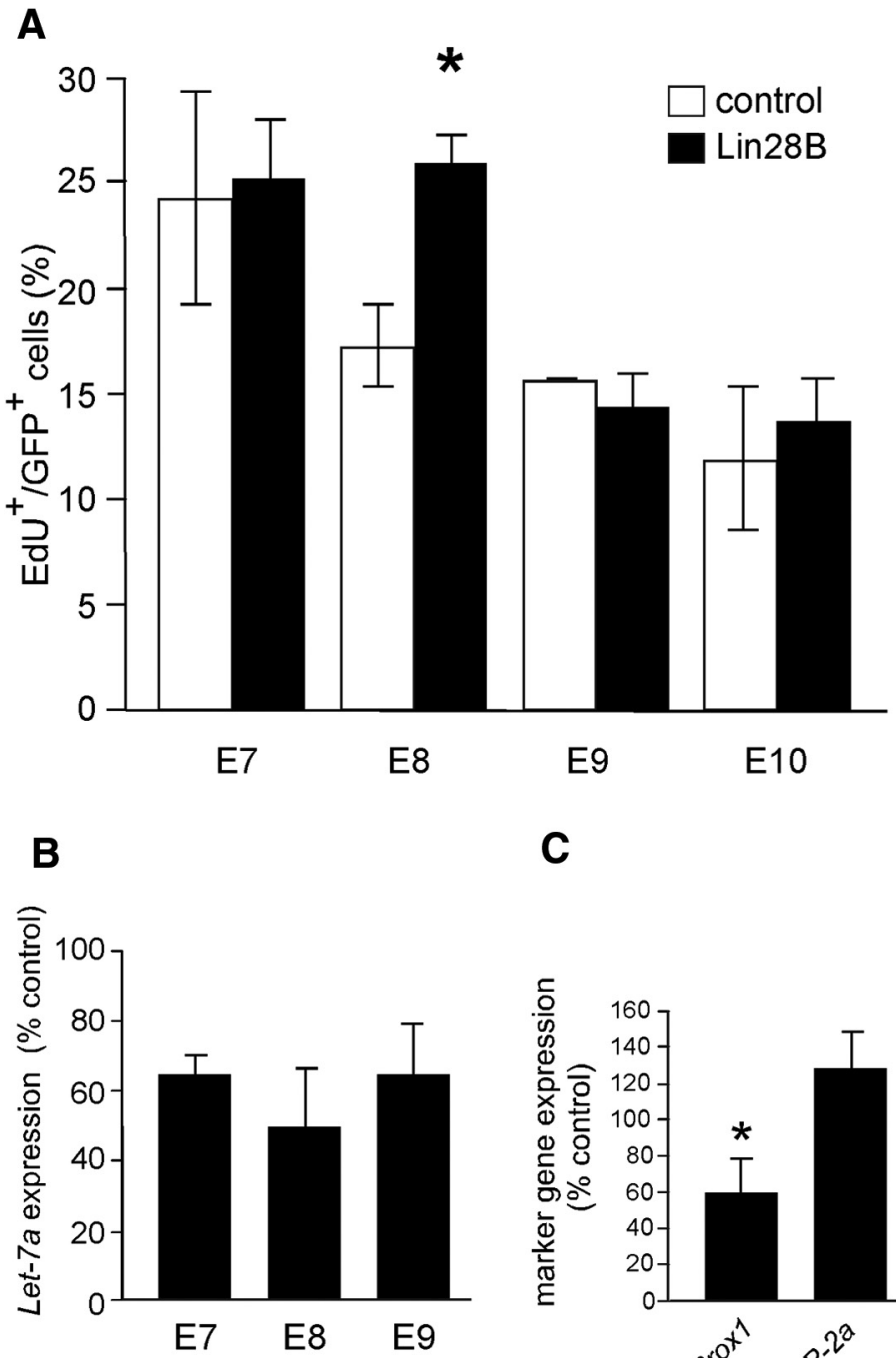

\section{C}

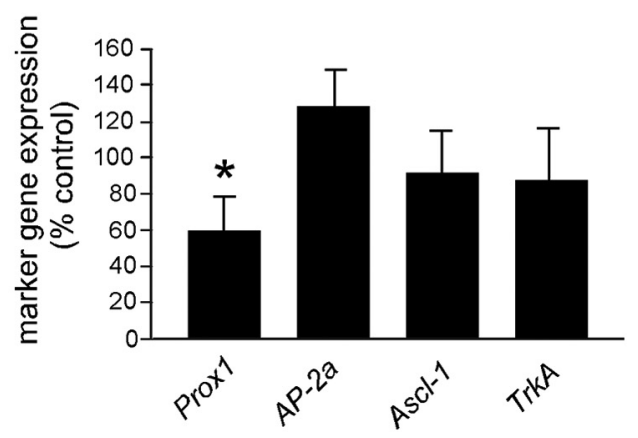

Figure 6. Overexpression of Lin28B increases proliferation of E8 neuroblasts, but does not affect Let-7a expression. $\boldsymbol{A}$, Forced E9, and E10 ganglia. $\boldsymbol{B}$, Let-7a expression is not significantly affected by Lin28B overexpression at all ages analyzed $(p=0.236$ 0.232 , and 0.335 for E7, E8, and E9, respectively). C, Forced expression of Lin28B in E8 neuroblasts results in reduced Prox expression ( $\left.{ }^{*} p<0.05\right)$, but does not affect $A s c 11, A P-2 a$, and $\operatorname{TrkA}(p=0.034,0.83,0.71$, and 0.5 for Prox1, Ascl1, AP-2a, and TrkA, respectively; $q \mathrm{RT}-\mathrm{PCR}$ analysis, mean $\pm \mathrm{SEM} ; n=3-6$; statistical analysis by REST).

Let-7 expression in sympathetic ganglia was analyzed by qRTPCR for Let-7a and by using a Let-7 sensor. Let-7a, commonly used as representative member of the Let-7 family (Viswanathan et al., 2009; Molenaar et al., 2012), is detectable at E6.5, the earliest time point sympathetic ganglia can be dissected in the chick embryo. During neurogenesis, Let-7a expression continuously increases up to E12, when the ganglia are mainly composed of postmitotic sympathetic neurons (Holzmann et al., 2015). Transfection of sympathetic ganglion cells with a Let-7 sensor revealed that already at E6.5, $74 \pm 5 \%$ of neuroblasts contained sufficient levels of Let-7 to degrade the sensor RNA. The sixfold increase in Let-7a expression observed by qRT-PCR thus reflects increased expression per cell rather than an increase in the number of Let7-expressing cells.

Lin28A/B and Let-7 function in developing sympathetic ganglia The increase in Let-7a expression between E6.5 and E12 parallels the increase in the percentage of postmitotic neurons from 5 to 85\% between E5 and E11 (Holzmann et al., 2015), suggesting that 
A
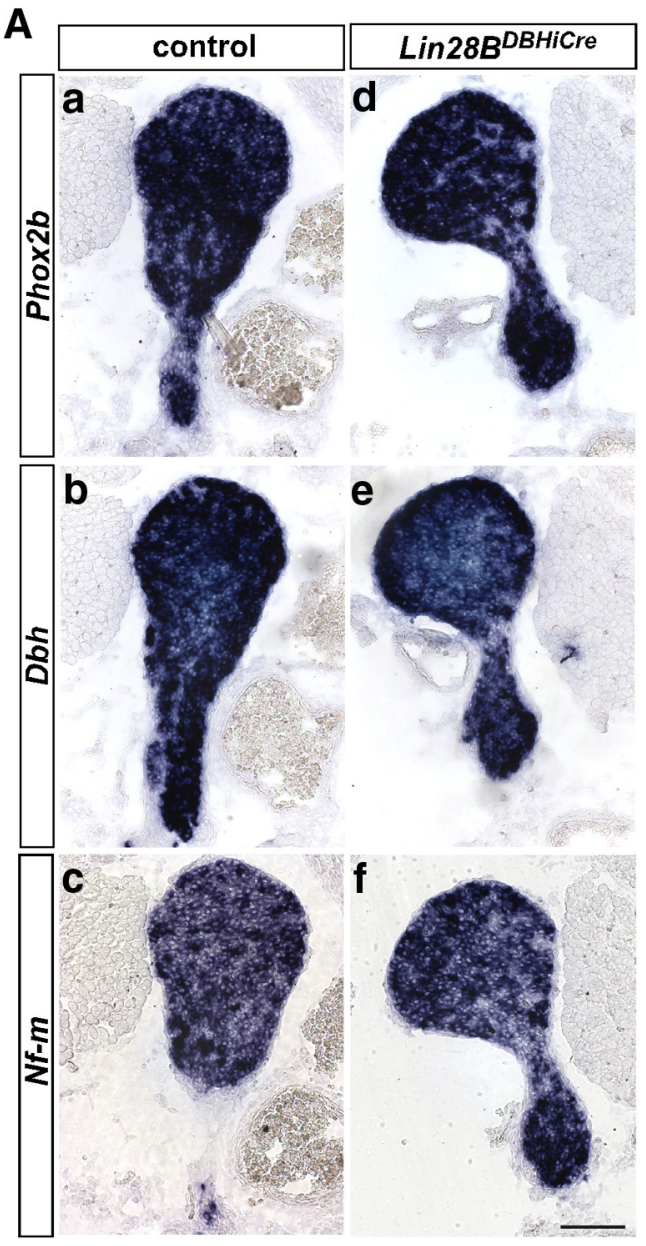

E

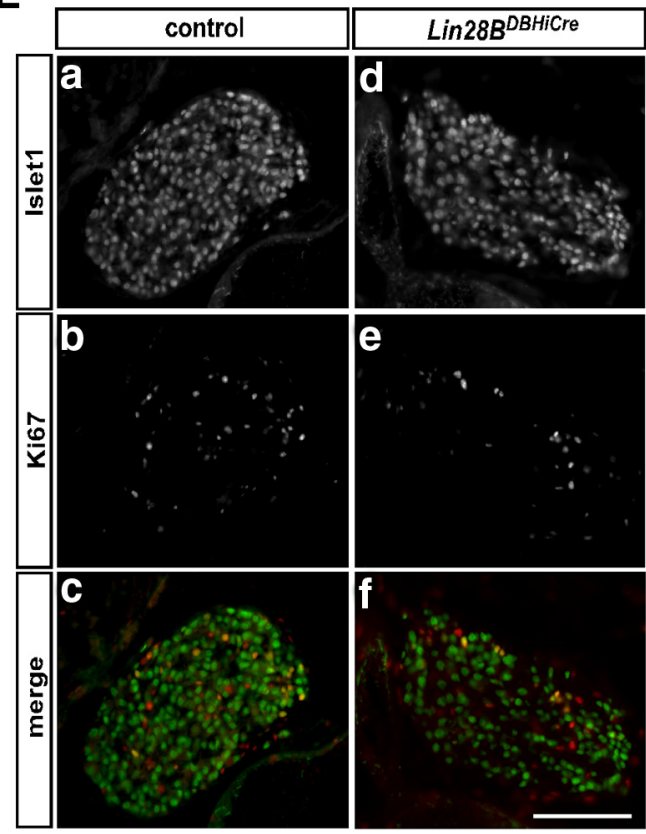

B control

Lin28B

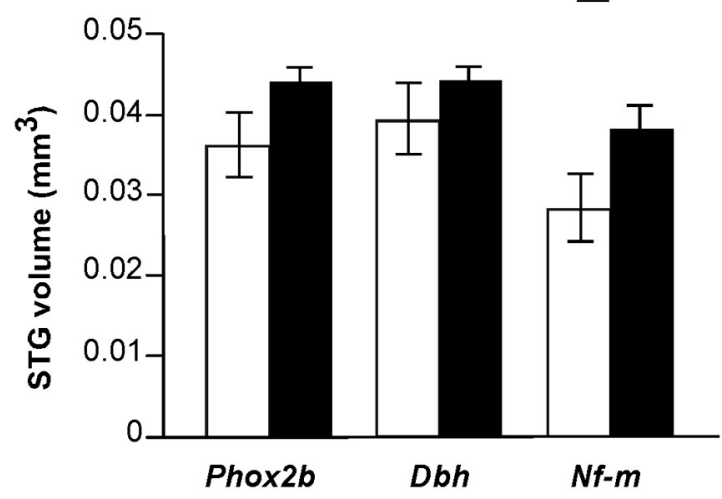

C

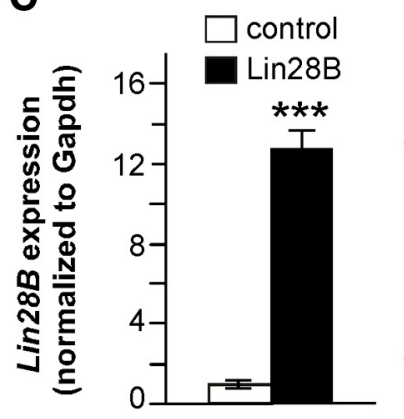

D

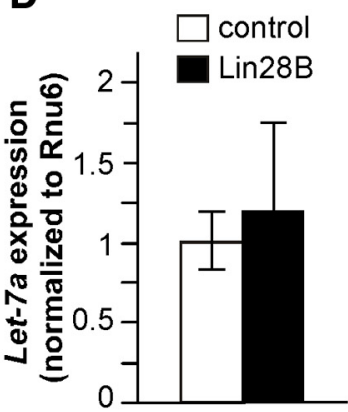

F

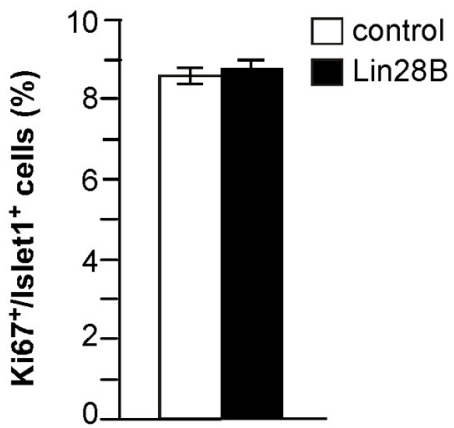

Figure 7. P0 sympathetic ganglia in LSL-Lin28B Dbhicre mice display normal size, Let-7 expression, and differentiation. $A$, Sections from the brachial region (STG) of PO control and LSL-Lin28BDbhicre mice were analyzed by in situ hybridization for the expression of Phox $2 b, D b h$, and Nf-m. $B$, The STG volume was calculated from morphometric quantification of stained areas in serial sections (mean \pm SEM; $n=4$ ). C, The expression level of $L$ in28B (normalized to Gapdh) in POSTGs and SCGs was investigated by qRT-PCR and reveals a 12 -fold increase in $L S L$-Lin28D ${ }^{\text {Dbhicre }}$ mice (mean \pm $\mathrm{SEM} ; n=10$ for LSL-LIn28B ${ }^{\text {Dhiicre }} ; n=3$ for controls; statistical analysis by REST). ${ }^{* * *} p<0.001$. D, qRT-PCR analysis of Let-7a expression (normalized to RNU6) in SCGs and STGs of control and

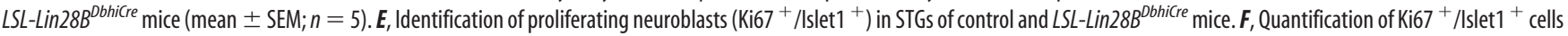
(mean \pm SEM; $n=4)$. Scale bars, $100 \mu \mathrm{m}$. 
Let-7 interferes with cell proliferation as established in several other lineages (Schwamborn et al., 2009; Zhao et al., 2010). This notion was confirmed in sympathetic neuroblast cultures by the increase in proliferation resulting from Let-7 inhibition. Lin28A and Lin28B, in contrast, are required for neuroblast proliferation, as blocking their expression by siRNA strongly reduces neuroblast proliferation. These experiments establish a function for endogenous Lin28 and Let-7 in sympathetic neuron proliferation. It was expected from the cross-regulatory expression of Let-7 and Lin 28 in stem cells and tumor tissues (Viswanathan et al., 2009; Thornton and Gregory, 2012) that reduced proliferation upon $\operatorname{Lin} 28$ knockdown is caused by increased Let-7 expression. Unexpectedly, Lin28B overexpression in cultured neuroblasts does not lead to the strong Let-7 downregulation observed in many cell types, including neural stem cells (La Torre et al., 2013) and tumor cells (Viswanathan et al., 2009), nor is proliferation enhanced at all stages when endogenous $\operatorname{Lin} 28 B$ is required for proliferation. Only at one particular stage of development, E8, was increased proliferation observed in response to Lin $28 B$ overexpression. This result demonstrates that ectopically expressed $\operatorname{Lin} 28 \mathrm{~B}$ is functional and that Lin28B increases proliferation without significantly affecting Let-7a levels. Because Lin28 directly binds and influences the translation of a multitude of mRNAs including cyclins, cell cycledependent kinases, IGF-II, and glycolytic enzymes, Lin 28 can directly potentiate cell proliferation and metabolism, independent of Let-7 (Polesskaya et al., 2007; Xu et al., 2009; Graf et al., 2013; Hafner et al., 2013; Shyh-Chang and Daley, 2013). Notably, progenitor proliferation and prevention of cell cycle exit in the developing cerebral cortex does not involve Let-7 (Let-7a-d), but rather Igf2-mTor signaling (Yang et al., 2015). Because IGFs have been shown previously to control sympathetic neuroblast proliferation (Zackenfels et al., 1995), we hypothesize that altered IGF signaling rather than Let-7 expression may underlie the Lin $28 \mathrm{~B}$ effects.

But how can the timing of the effects of Lin $28 \mathrm{~B}$ overexpression to a particular stage of development be explained? If Lin28B acts as heterochronic gene and shifts the identity of neuroblasts toward earlier stages, an increased proliferation at E9 and E10 would be expected. A heterochronic function is also excluded by the finding that marker genes for progenitors and early neuroblasts (Ascl1, AP-2a, Prox1; Guillemot and Joyner, 1993; Schmidt et al., 2011; Holzmann et al., 2015) are not upregulated in response to $\operatorname{Lin} 28 B$ overexpression. A more likely explanation is that neuroblasts change their properties during neurogenesis, which is reflected by different sympathetic neuron phenotypes produced (Chubb and Anderson, 2010) and may also affect the response to $\operatorname{Lin} 28 B$ overexpression. Although the mechanisms
B

C

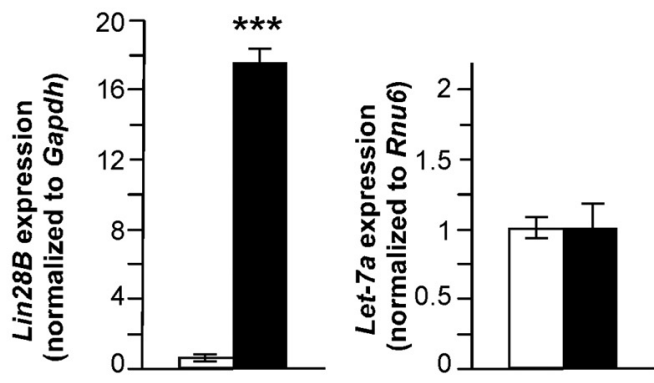

Figure 8. P15-P20 sympathetic ganglia in LSL-Lin28B ${ }^{\text {Dbhlcre }}$ display normal size and Let-7 expression, whereas Lin28B-induced ganglonic tumors are virtually devoid of Let-7a.A, The SCG volume of P20 LSL-Lin28B ${ }^{\text {Dbhicre }}$ and control mice was calculated from LSL- mice compared to controls (mean \pm SEM; $n=5$; statistical analysis by REST). ${ }^{* * *} p<0.001$. C, qRT-PCR analysis t-7a expression (normalized to RNU6) in P15 SCGs and STGs of control and LSL-Lin28B ${ }^{\text {Dbhicre }}$ mice (mean \pm SEM; $n=8$ for

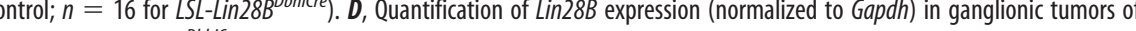
(SCG + STG; mean + SEM; $n=5 ;$ statistical analysis by REST). $E$, qRT-PCR analysis of Let-7a expression in ganglionic tumors of

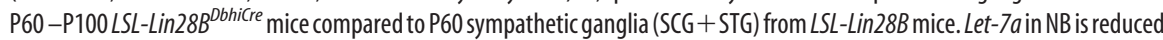
to $0.005 \pm 0.001$ compared to control ganglia (mean $\pm \mathrm{SEM} ; n=5$; statistical analysis by REST). ${ }^{* *} p<0.01 ;{ }^{* * *} p<0.001$.

that are responsible for the developmental restriction of $\operatorname{Lin} 28 B$ effects remain unclear, our findings allow the conclusion that Lin $28 B$ overexpression does not lead to a general prolongation of neuroblast proliferation and reduced Let-7a expression.

\section{Lin28B function in the LSL-Lin28B ${ }^{\text {DBHiCre }}$ NB mouse model}

Lin 28 regulates the timing of differentiation of embryonic tissues and is upregulated in poorly differentiated tumors (Ambros and Horvitz, 1984; Moss et al., 1997; Viswanathan and Daley, 2010). This suggests a function for Lin28 in tumor development by maintaining stem and progenitor cells or by Lin28-induced dedifferentiation. Indeed, Lin28A overexpression has been implicated in pediatric tumor formation, which is caused by a failure of differentiation (Gillis et al., 2011; Urbach et al., 2014). Neuroblastoma elicited by forced Lin $28 B$ expression in noradrenergic neuroblasts was also considered to be due to progenitor maintenance and failed terminal differentiation (Marshall et al., 2014). Our present analysis of sympathoadrenal cells in a Lin $28 B$ overexpressing mouse line reveals that sympathetic ganglia and adrenal medulla are indistinguishable from controls with respect to tissue size, expression of differentiation markers, proliferation, and Let-7a expression up to P20, although the Cre-recombinase in Lin $28 B^{\text {DBHiCre }}$ animals is expected to initiate Lin28B expression at early embryonic stages (E11.5; Parlato et al., 2007; Tsar- 
A

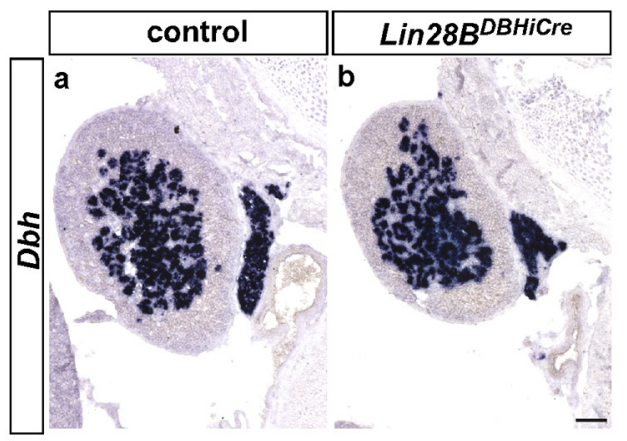

B

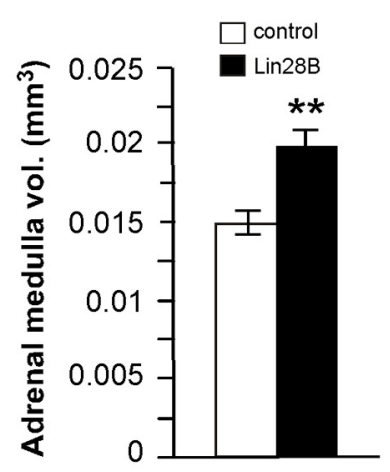

C

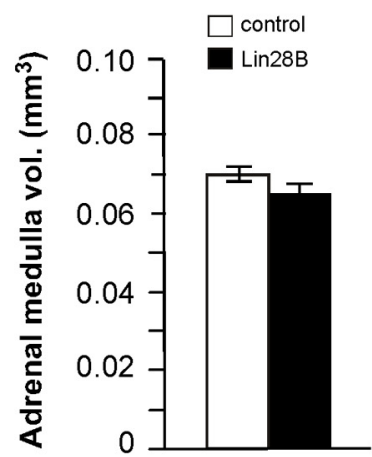

D

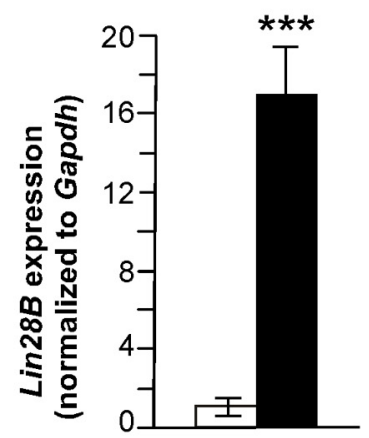

F

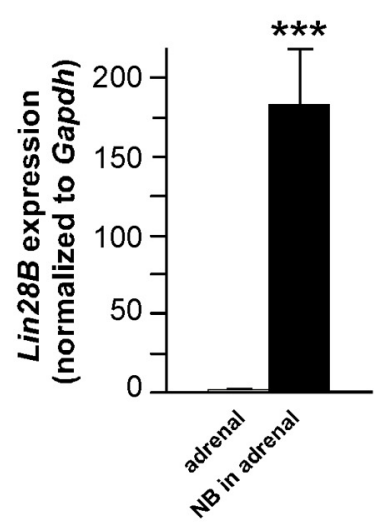

E

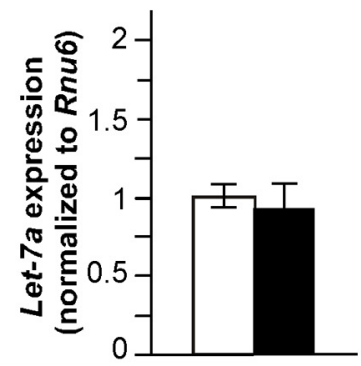

G

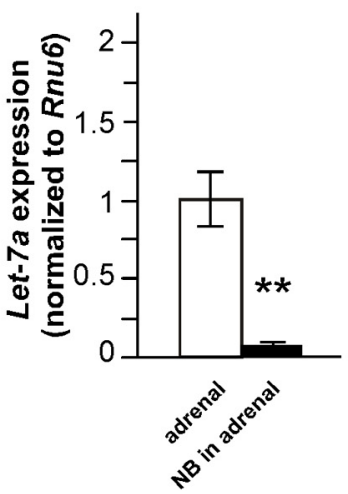

Figure 9. Adrenal medulla in LSL-Lin28B Dbhicre mice display normal size and Let-7 expression up to P20, whereas Lin28B-induced tumors show strongly reduced Let-7a expression. A, Adrenals from PO control and LSL-Lin28BDbhicre mice analyzed by in situ hybridization for Dbh expression. Scale bar, $100 \mu \mathrm{m}$. B, PO adrenal medulla volume calculated from Dbh-stained serial sections from LSL-Lin28B Dbhicre and control mice (mean \pm SEM; $n=7$ for control; $n=9$ for $L S L$-Lin28B Dbhicre). C, P20 adrenal medulla volume calculated from Dbh-stained serial sections does not differ between LSL-Lin28B ${ }^{\text {Dbhicre }}$ and controls (mean \pm SEM $; n=8$ for control; $n=12$ for LSL-Lin28B ${ }^{\text {Dbhicre }) . D, ~ Q u a n t i f i c a t i o n ~ o f ~} L$ in 28B expression in P15/P16 adrenal glands by qRT-PCR reveals a 17-fold increase in $L S L$-Lin28B Dbhicre mice (mean \pm SEM; $n=3$; statistical analysis by REST). E, qRT-PCR analysis of Let-7a expression in P15/P16 adrenal glands of control and $L S L$-Lin28B Dbhicre mice (mean \pm SEM; $n=5$ ). $\boldsymbol{F}$, Quantification of $L$ in28B expression in adrenal tumors of P60-P100 LSL-Lin28B Dohicre mice by qRT-PCR reveals a 175 -fold increase compared to P60 control adrenals (mean \pm SEM; $n=$ 5 ; statistical analysis by REST). G, qRT-PCR analysis of Let-7a expression in adrenal tumors of P60-P100 LSL-Lin28B Dbhicre mice compared to P60 LSL-Lin28B control adrenals. Let-7a in NB is reduced to $0.07 \pm 0.01$ compared to control adrenals (mean $\pm \mathrm{SEM} ; n=5$; statistical analysis by REST). ${ }^{* *} p<0.01 ;{ }^{* * *} p<0.001$.

ovina et al., 2010; Majdazari et al., 2013). Given that cultured sympathetic neuroblasts also show a limited proliferation response to $\operatorname{Lin} 28 B$, we conclude that $\operatorname{Lin} 28 B$ overexpressison is not sufficient to maintain neuroblasts in the cell cycle. In addition, in both chick and mouse neuroblasts, Lin28B overexpression does not lead to decreased Let-7a levels.

These results suggest that the strongly reduced Let-7 levels observed in ganglionic and adrenal tumors of $\operatorname{Lin} 28 B^{D B H i C r e}$ mice may not be directly and exclusively linked to increased Lin28B levels in sympathetic neuroblasts. In addition, they raise the question as to the identity of Lin28B targets that eventually lead to NB development. Previous evidence suggests that mRNAs in addition to microRNAs are major Lin28 targets (Cho et al., 2012; Hafner et al., 2013). Direct targets of Lin 28 with increased mRNA translation and/or stabilization include genes contributing to cell cycle regulation (e.g., CyclinD1/D2, Cyclin B1, Cdk1/2) and components of the IGF2-PI3K-mTor signaling pathway (Polesskaya et al., 2007; Xu et al., 2009; Yang et al., 2015). Given that mTOR signaling affects translation and stabilization of MYC proteins (West et al., 1998; Johnsen et al., 2008; Sun and Jin, 2008) and MYCN activates and sustains the mTOR pathway (Pourdehnad et al., 2013; Schramm et al., 2013; Moore et al., 2014), it is 

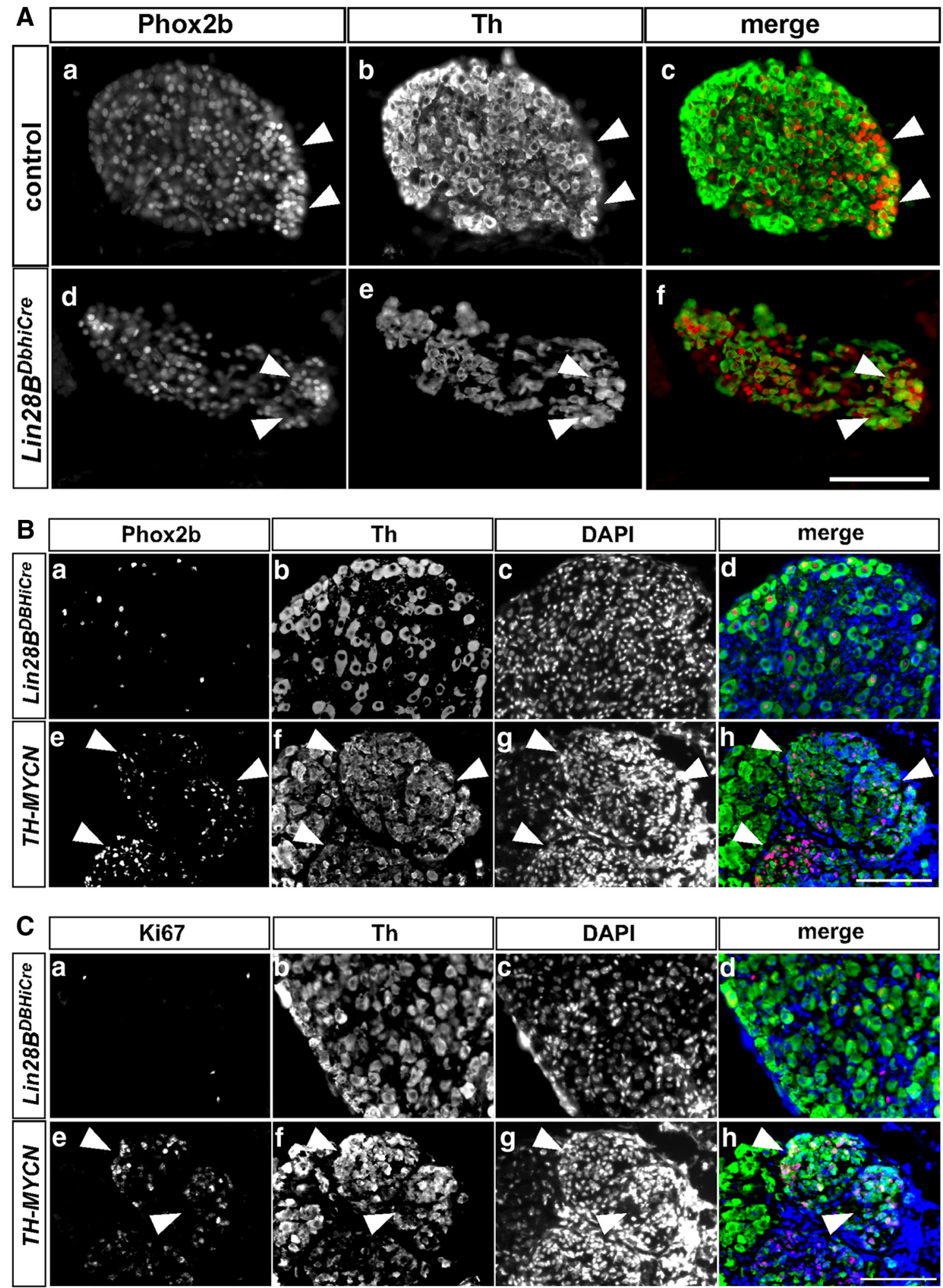

Figure 10. Clusters of proliferating $\mathrm{Ki}_{6} \mathrm{7}^{+}$and Phox $2 \mathrm{~b}^{+}$neuroblasts are not observed in sympathetic ganglia of $L S L-L i n 28 B^{D b h i c r e}$ at P2O. A, Double immunostaining for Phox $2 \mathrm{~b}$ and Th on frozen sections of PO SCGs reveals clusters of Phox $2 \mathrm{~b}^{+} / \mathrm{Th}^{+}$cells (arrowheads) in ganglia of both control and LSL-Lin28B Dhhlcre mice. $B$, At P20 -P22, clusters of Phox2b ${ }^{+}$cells are absent in LSL-

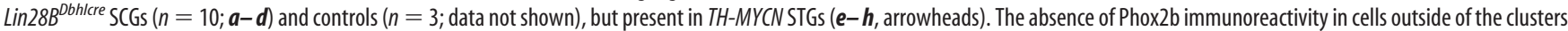
$(\boldsymbol{e}$, in contrast to $\boldsymbol{a})$ is explained by different fixation conditions. $\boldsymbol{C}, K_{167}{ }^{+}$cells are scarce and show a scattered distribution in P22 STGs of $L S L$-Lin28BDbhlcre $(\boldsymbol{a}-\boldsymbol{d} ; n=8)$ and $\operatorname{control}(n=4 ;$ data not shown) mice. Less than $1 \%$ of all DAPI ${ }^{+}$nuclei are Ki67 ${ }^{+}$in control and LSL-Lin28B Dbhicre mice. In contrast, clusters of Ki67 ${ }^{+}$cells with low Th levels are detected in P20 SCGs of $T H-M Y C N$ mice (e-h, arrowheads). Scale bars, $100 \mu \mathrm{m}$. 
tempting to speculate that $\mathrm{NB}$ initiation in postnatal $L S L$ Lin $28 B^{\text {DbhiCre }}$ mice may involve increased translation of IGF-2mTor signal pathway components leading to an increase in MYCN protein. In tumors of adult LSL-Lin $28 B^{\text {DbhiCre }}$ mice, reduced Let-7 expression contributes to the stabilization of endogenous MYCN, which drives tumor growth as shown by reduced tumor size upon treatment with the MYCN antagonist JQ-1 (Molenaar et al., 2012). Together, the present results argue against a role for Let-7 and rather implicate other Lin28B targets during the initial stages of NB development.

\section{References}

Alam G, Cui H, Shi H, Yang L, Ding J, Mao L, Maltese WA, Ding HF (2009) MYCN promotes the expansion of Phox2B-positive neuronal progenitors to drive neuroblastoma development. Am J Pathol 175:856-866. CrossRef Medline

Ambros V, Horvitz HR (1984) Heterochronic mutants of the nematode Caenorhabditis elegans. Science 226:409-416. CrossRef Medline

Balzer E, Heine C, Jiang Q, Lee VM, Moss EG (2010) LIN28 alters cell fate succession and acts independently of the let-7 microRNA during neurogliogenesis in vitro. Development 137:891-900. CrossRef Medline

Brodeur GM (2003) Neuroblastoma: biological insights into a clinical enigma. Nat Rev Cancer 3:203-216. CrossRef Medline

Cho J, Chang H, Kwon SC, Kim B, Kim Y, Choe J, Ha M, Kim YK, Kim VN (2012) LIN28A is a suppressor of ER-associated translation in embryonic stem cells. Cell 151:765-777. CrossRef Medline

Chubb DP, Anderson CR (2010) The relationship of the birth date of rat sympathetic neurons to the target they innervate. Dev Dyn 239:897-904. CrossRef Medline

Diskin SJ, Capasso M, Schnepp RW, Cole KA, Attiyeh EF, Hou C, Diamond M, Carpenter EL, Winter C, Lee H, Jagannathan J, Latorre V, Iolascon A, Hakonarson H, Devoto M, Maris JM (2012) Common variation at 6q16 within HACE1 and LIN28B influences susceptibility to neuroblastoma. Nat Genet 44:1126-1130. CrossRef Medline

Ernsberger U, Patzke H, Rohrer H (1997) The developmental expression of choline acetyltransferase (ChAT) and the neuropeptide VIP in chick sympathetic neurons: evidence for different regulatory events in cholinergic differentiation. Mech Dev 68:115-126. CrossRef Medline

Frost RJ, Olson EN (2011) Control of glucose homeostasis and insulin sensitivity by the Let-7 family of microRNAs. Proc Natl Acad Sci U S A 108: 21075-21080. CrossRef Medline

Gillis AJ, Stoop H, Biermann K, van Gurp RJ, Swartzman E, Cribbes S, Ferlinz A, Shannon M, Oosterhuis JW, Looijenga LH (2011) Expression and interdependencies of pluripotency factors LIN28, OCT3/4, NANOG and SOX2 in human testicular germ cells and tumours of the testis. Int J Androl 34:e160-e174. CrossRef Medline

Gonsalvez DG, Cane KN, Landman KA, Enomoto H, Young HM, Anderson CR (2013) Proliferation and cell cycle dynamics in the developing stellate ganglion. J Neurosci 33:5969-5979. CrossRef Medline

Graf R, Munschauer M, Mastrobuoni G, Mayr F, Heinemann U, Kempa S, Rajewsky N, Landthaler M (2013) Identification of LIN28B-bound mRNAs reveals features of target recognition and regulation. RNA Biol 10: 1146-1159. CrossRef Medline

Guillemot F, Joyner AL (1993) Dynamic expression of the murine AchaeteScute homologue Mash-1 in the developing nervous system. Mech Dev 42:171-185. CrossRef Medline

Gundersen HJ, Bendtsen TF, Korbo L, Marcussen N, Møller A, Nielsen K, Nyengaard JR, Pakkenberg B, Sørensen FB, Vesterby A, West MJ (1988) Some new, simple and efficient stereological methods and their use in pathological research and diagnosis. APMIS 96:379-394. CrossRef Medline

Hafner M, Max KE, Bandaru P, Morozov P, Gerstberger S, Brown M, Molina $\mathrm{H}$, Tuschl T (2013) Identification of mRNAs bound and regulated by human LIN28 proteins and molecular requirements for RNA recognition. RNA 19:613-626. CrossRef Medline

Hamburger V, Hamilton HL (1951) A series of normal stages in the development of the chick embryo. J Exp Zool 88:49-92.

Hansford LM, Thomas WD, Keating JM, Burkhart CA, Peaston AE, Norris MD, Haber M, Armati PJ, Weiss WA, Marshall GM (2004) Mechanisms of embryonal tumor initiation: distinct roles for $\mathrm{MycN}$ expression and MYCN amplification. Proc Natl Acad Sci U S A 101:12664-12669. CrossRef Medline
Helms AW, Johnson JE (2003) Specification of dorsal spinal cord interneurons. Curr Opin Neurobiol 13:42-49. CrossRef Medline

Holzmann J, Hennchen M, Rohrer H (2015) Prox1 identifies proliferating neuroblasts and nascent neurons during neurogenesis in sympathetic ganglia. Dev Neurobiol 12:1352-1367. CrossRef Medline

Johnsen JI, Segerström L, Orrego A, Elfman L, Henriksson M, Kågedal B, Eksborg S, SveinbjörnssonB, Kogner P (2008) Inhibitors of mammalian target of rapamycin downregulate MYCN protein expression and inhibit neuroblastoma growth in vitro and in vivo. Oncogene 27:2910-2922. CrossRef Medline

La Torre A, Georgi S, Reh TA (2013) Conserved microRNA pathway regulates developmental timing of retinal neurogenesis. Proc Natl Acad Sci U S A 110:E2362-E2370. CrossRef Medline

Majdazari A, Stubbusch J, Müller CM, Hennchen M, Weber M, Deng CX, Mishina Y, Schütz G, Deller T, Rohrer H (2013) Dendrite complexity of sympathetic neurons is controlled during postnatal development by BMP signaling. J Neurosci 33:15132-15144. CrossRef Medline

Maris JM, Hogarty MD, Bagatell R, Cohn SL (2007) Neuroblastoma. Lancet 369:2106-2120. CrossRef Medline

Marshall GM, Carter DR, Cheung BB, Liu T, Mateos MK, Meyerowitz JG, Weiss WA (2014) The prenatal origins of cancer. Nat Rev Cancer 14: 277-289. CrossRef Medline

Molenaar JJ, Domingo-Fernández R, Ebus ME, Lindner S, Koster J, Drabek K, Mestdagh P, van Sluis P, Valentijn LJ, van Nes J, Broekmans M, Haneveld F, Volckmann R, Bray I, Heukamp L, Sprüssel A, Thor T, Kieckbusch K, Klein-Hitpass L, Fischer M, et al. (2012) LIN28B induces neuroblastoma and enhances MYCN levels via let-7 suppression. Nature Genet 44:1199-1206. CrossRef Medline

Moore NF, Azarova AM, Bhatnagar N, Ross KN, Drake LE, Frumm S, Liu QS, Christie AL, Sanda T, Chesler L, Kung AL, Gray NS, Stegmaier K, George RE (2014) Molecular rationale for the use of PI3K/AKT/mTOR pathway inhibitors in combination with crizotinib in ALK-mutated neuroblastoma. Oncotarget 5:8737-8749. CrossRef Medline

Moss EG, Lee RC, Ambros V (1997) The cold shock domain protein LIN-28 controls developmental timing in C. elegans and is regulated by the lin- 4 RNA. Cell 88:637-646. CrossRef Medline

Nguyen LH, Robinton DA, Seligson MT, Wu L, Li L, Rakheja D, Comerford SA, Ramezani S, Sun X, Parikh MS, Yang EH, Powers JT, Shinoda G, Shah SP, Hammer RE, Daley GQ, Zhu H (2014) Lin28b is sufficient to drive liver cancer and necessary for its maintenance in murine models. Cancer Cell 26:248-261. CrossRef Medline

Parlato R, Otto C, Begus Y, Stotz S, Schütz G (2007) Specific ablation of the transcription factor CREB in sympathetic neurons surprisingly protects against developmentally regulated apoptosis. Development 134: 1663-1670. CrossRef Medline

Pattyn A, Morin X, Cremer H, Goridis C, Brunet JF (1997) Expression and interactions of the two closely related homeobox genes Phox $2 a$ and Phox2b during neurogenesis. Development 124:4065-4075. Medline

Pfaffl MW, Horgan GW, Dempfle L (2002) Relative expression software tool (REST) for group-wise comparison and statistical analysis of relative expression results in real-time PCR. Nucleic Acids Res 30:e36. CrossRef Medline

Polesskaya A, Cuvellier S, Naguibneva I, Duquet A, Moss EG, Harel-Bellan A (2007) Lin-28 binds IGF-2 mRNA and participates in skeletal myogenesis by increasing translation efficiency. Genes Dev 21:1125-1138. CrossRef Medline

Pourdehnad M, Truitt ML, Siddiqi IN, Ducker GS, Shokat KM, Ruggero D (2013) Myc and mTOR converge on a common node in protein synthesis control that confers synthetic lethality in Myc-driven cancers. Proc Natl Acad Sci U S A 110:11988-11993. CrossRef Medline

Ramachandran R, Fausett BV, Goldman D (2010) Asclla regulates Muller glia dedifferentiation and retinal regeneration through a Lin-28dependent, let-7 microRNA signalling pathway. Nat Cell Biol 12: 1101-1107. CrossRef Medline

Reiff T, Huber L, Kramer M, Delattre O, Janoueix-Lerosey I, Rohrer H (2011) Midkine and Alk signaling in sympathetic neuron proliferation and neuroblastoma predisposition. Development 138:4699-4708. CrossRef Medline

Rohrer H (2011) Transcriptional control of differentiation and neurogenesis in autonomic ganglia. Eur J Neurosci 34:1563-1573. CrossRef Medline

Rohrer H, Thoenen H (1987) Relationship between differentiation and terminal mitosis: chick sensory and ciliary neurons differentiate after termi- 
nal mitosis of precursor cells whereas sympathetic neurons continue to divide after differentiation. J Neurosci 7:3739-3748. Medline

Rohrer H, Acheson AL, Thibault J, Thoenen H (1986) Developmental potential of quail dorsal root ganglion cells analyzed in vitro and in vivo. J Neurosci 6:2616-2624. Medline

Rothman TP, Gershon MD, Holtzer H (1978) The relationship of cell division to the acquisition of adrenergic characteristics by developing sympathetic ganglion cell precursors. Dev Biol 65:321-341.

Rybak A, Fuchs H, Smirnova L, Brandt C, Pohl EE, Nitsch R, Wulczyn FG (2008) A feedback loop comprising lin-28 and let-7 controls pre-let-7 maturation during neural stem-cell commitment. Nat Cell Biol 10: 987-993. CrossRef Medline

Schmidt M, Huber L, Majdazari A, Schütz G, Williams T, Rohrer H (2011) The transcription factors AP-2beta and AP-2alpha are required for survival of sympathetic progenitors and differentiated sympathetic neurons. Dev Biol 355:89-100. CrossRef Medline

Schramm A, Köster J, Marschall T, Martin M, Schwermer M, Fielitz K, BüchelG, Barann M, Esser D, Rosenstiel P, Rahmann S, Eggert A, Schulte JH (2013) Next-generation RNA sequencing reveals differential expression of MYCN target genes and suggests the mTOR pathway as a promising therapy target in MYCN-amplified neuroblastoma. Int J Cancer 132:E106-E115. CrossRef Medline

Schwamborn JC, Berezikov E, Knoblich JA (2009) The TRIM-NHL protein TRIM32 activates microRNAs and prevents self-renewal in mouse neural progenitors. Cell 136:913-925. CrossRef Medline

Shyh-Chang N, Daley GQ (2013) Lin28: primal regulator of growth and metabolism in stem cells. Cell Stem Cell 12:395-406. CrossRef Medline

Stanke M, Duong CV, Pape M, Geissen M, Burbach G, Deller T, Gascan H, Otto C, Parlato R, Schütz G, Rohrer H (2006) Target-dependent specification of the neurotransmitter phenotype: cholinergic differentiation of sympathetic neurons is mediated in vivo by gp130 signaling. Development 133:141-150. CrossRef Medline

Stubbusch J, Narasimhan P, Hennchen M, Huber K, Unsicker K, Ernsberger U, Rohrer H (2014) Lineage and stage specific requirement for Dicerl in sympathetic ganglia and adrenal medulla formation and maintenance. Dev Biol 400:210-223. CrossRef

Sun J, Jin T (2008) Both Wnt and mTOR signaling pathways are involved in insulin-stimulated proto-oncogene expression in intestinal cells. Cell Signal 20:219-229. CrossRef Medline

Thornton JE, Gregory RI (2012) How does Lin28 let-7 control development and disease? Trends Cell Biol 22:474-482. CrossRef Medline

Tsarovina K, Schellenberger J, Schneider C, Rohrer H (2008) Progenitor cell maintenance and neurogenesis in sympathetic ganglia involves Notch signaling. Mol Cell Neurosci 37:20-31. CrossRef Medline

Tsarovina K, Reiff T, Stubbusch J, Kurek D, Grosveld FG, Parlato R, Schütz G, Rohrer H (2010) The Gata3 transcription factor is required for the survival of embryonic and adult sympathetic neurons. J Neurosci 30:1083310843. CrossRef Medline

Urbach A, Yermalovich A, Zhang J, Spina CS, Zhu H, Perez-Atayde AR, Shukrun R, Charlton J, Sebire N, Mifsud W, Dekel B, Pritchard-Jones K, Daley GQ (2014) Lin28 sustains early renal progenitors and induces Wilms tumor. Genes Dev 28:971-982. CrossRef Medline
Vadla B, Kemper K, Alaimo J, Heine C, Moss EG (2012) lin-28 controls the succession of cell fate choices via two distinct activities. PLoS Genet 8:e1002588. CrossRef Medline

Viswanathan SR, Daley GQ (2010) Lin28: A microRNA regulator with a macro role. Cell 140:445-449. CrossRef Medline

Viswanathan SR, Powers JT, Einhorn W, Hoshida Y, Ng TL, Toffanin S, O’Sullivan M, Lu J, Phillips LA, Lockhart VL, Shah SP, Tanwar PS, Mermel CH, Beroukhim R, Azam M, Teixeira J, Meyerson M, Hughes TP, Llovet JM, Radich J, et al. (2009) Lin28 promotes transformation and is associated with advanced human malignancies. Nat Genet 41:843-848. CrossRef Medline

Von Holst A, Lefcort F, Rohrer H (1997) TrkA expression levels of sympathetic neurons correlate with NGF-dependent survival during development and after treatment with retinoic acid. Eur J Neurosci 9:2169-2177. CrossRef Medline

Wakamatsu Y, Maynard TM, Weston JA (2000) Fate determination of neural crest cells by NOTCH-mediated lateral inhibition and asymmetrical cell division during gangliogenesis. Development 127:2811-2821. Medline

Weiss WA, Aldape K, Mohapatra G, Feuerstein BG, Bishop JM (1997) Targeted expression of MYCN causes neuroblastoma in transgenic mice. EMBO J 16:2985-2995. CrossRef Medline

West MJ, Stoneley M, Willis AE (1998) Translational induction of the c-myc oncogene via activation of the FRAP/TOR signalling pathway. Oncogene 17:769-780. CrossRef Medline

Wulczyn FG, Smirnova L, Rybak A, Brandt C, Kwidzinski E, Ninnemann O, Strehle M, Seiler A, Schumacher S, Nitsch R (2007) Post-transcriptional regulation of the let-7 microRNA during neural cell specification. FASEB J 21:415-426. CrossRef Medline

Xu B, Zhang K, Huang Y (2009) Lin28 modulates cell growth and associates with a subset of cell cycle regulator mRNAs in mouse embryonic stem cells. RNA 15:357-361. CrossRef Medline

Yang DH, Moss EG (2003) Temporally regulated expression of Lin-28 in diverse tissues of the developing mouse. Gene Expr Patterns 3:719-726. CrossRef Medline

Yang M, Yang SL, Herrlinger S, Liang C, Dzieciatkowska M, Hansen KC, Desai R, Nagy A, Niswander L, Moss EG, Chen JF (2015) Lin28 promotes the proliferative capacity of neural progenitor cells in brain development. Development 142:1616-1627. CrossRef Medline

Yue Y, Zhang D, Jiang S, Li A, Guo A, Wu X, Xia X, Cheng H, Tao T, Gu X (2014) LIN28 expression in rat spinal cord after injury. Neurochem Res 39:862-874. CrossRef Medline

Zackenfels K, Oppenheim RW, Rohrer H (1995) Evidence for an important role of IGF-I and IGF-II for the early development of chick sympathetic neurons. Neuron 14:731-741. CrossRef Medline

Zhao C, Sun G, Li S, Lang MF, Yang S, Li W, Shi Y (2010) MicroRNA let-7b regulates neural stem cell proliferation and differentiation by targeting nuclear receptor TLX signaling. Proc Natl Acad Sci U S A 107:1876-1881. CrossRef Medline

Zhou J, Ng SB, Chng WJ (2013) LIN28/LIN28B: an emerging oncogenic driver in cancer stem cells. Int J Biochem Cell Biol 45:973-978. CrossRef Medline 